Shachaf, P., \& Horowitz, S. (2007). Virtual reference service evaluation: Adherence to RUSA behavioral guidelines and IFLA digital reference guidelines. Manuscript submitted for publication.

\title{
Virtual reference service evaluation: Adherence to RUSA behavioral guidelines and IFLA digital reference guidelines
}

\author{
Pnina Shachaf \\ School of Library and Information Science \\ Indiana University \\ 1320 East 10th Street, LI005A \\ Bloomington, IN 47405-3907 \\ E-mail: shachaf@indiana.edu \\ Sarah M. Horowitz \\ Thomas Tredway Library \\ Augustana College \\ 639 38th Street \\ Rock Island, IL 61201 \\ Email: sarahhorowitz@augustana.edu
}

\begin{abstract}
This study evaluates the level of adherence to professional guidelines by virtual (e-mail) reference services. These professional guidelines are set up as standards to assure service quality; however, studies of virtual reference effectiveness rarely utilize these standards to measure reference success. This study evaluates and compares the level of adherence to two sets of professional guidelines that have been published by the International Federation of Library Associations (IFLA) and the American Library Association (ALA) Reference and User Services Association (RUSA). Analysis of 324 transactions from 54 libraries showed: 1) low levels of adherence to both sets of guidelines; 2) varied levels of adherence based on request types and user names on both sets of guidelines; 3) variation in institutional rank when different sets of guidelines were utilized; 4) no correlation between user satisfaction and adherence to either set of guidelines. The implications of this study for future research and practice lie not only in its provision of a systematic way to analyze transactions in light of the ideal professional standards, but also in providing an empirical benchmark for virtual reference services evaluation.
\end{abstract}

\section{Introduction}

Academic libraries provide an unprecedented level of virtual services to their students, faculty, and staff; almost any academic library provides at least a minimal level of virtual reference service via e-mail ${ }^{1}$ (Coffman, 2003; Janes 2002; Stacy- Bates, 2003). As virtual

\footnotetext{
${ }^{1}$ In this study, virtual reference services refer to question answering services that libraries provide via email, an asynchronous channel of communication, either through a mailto link on a library website or a web form that users can fill out to ask reference questions online. These requests are answered by library employees via e-mail. Others have defined virtual reference as "reference service initiated electronically, often in real-time, where patrons employ computers or other Internet technology to communicate with reference staff, without being physically present. Communication channels used frequently in virtual reference include chat, videoconferencing, Voice over IP, co-browsing, e-mail, and instant messaging..."
} 
reference services mature, a rapidly growing body of literature examines the challenges and opportunities they produce (Radford, 2006). In an attempt to address the challenges that librarians face when planning, implementing, and evaluating virtual reference services, practitioners have published guidelines for librarians (Sloan, 1998). Similarly, professional associations, such as the International Federation of Library Associations (IFLA) and the Reference and User Services Association (RUSA) of the American Library Association (ALA), are composing, modifying, and publishing guidelines for virtual reference services (International Federation of Library Associations, 2005; Reference and User Services Association, 2004a; 2004b). As these guidelines set standards for effective virtual reference services, assessment of the level of implementation of IFLA and RUSA guidelines in practice can elucidate services' effectiveness. Yet, despite the potential value of the guidelines, studies of virtual reference effectiveness have rarely utilized them as standards for evaluation and only a few studies refer to them briefly (Kwan, 2004; 2006; Shachaf \& Horowitz, 2006; Walter \& Mediavilla, 2005; Ward, 2003; Zhuo, Love, Norwood, \& Massia, 2006). This study addresses the lacunae of empirical evaluation of virtual reference services in light of the standards by using the guidelines to evaluate virtual reference transactions. Using these guidelines as standards for systematic evaluation may provide feedback to service providers and inform decision makers.

\section{Evaluation of Virtual and Traditional Reference Services}

Evaluation of virtual reference services has been the focus of an ample number of recent studies. However, Arnold and Kaske (2005) argue that "most of the evaluations [of virtual reference services] conducted to date have been anecdotal in nature" (p. 178) and the need to conduct more studies of virtual reference service effectiveness has been emphasized (White, 2001). More recently Kwon (2007, p.72) claims that: "While there is an extensive body of literature examining the effectiveness of question answering, few have investigated the phenomenon empirically." While some researchers may argue for the need to develop new methods and measures of evaluation of virtual reference services (Hernon \& Calvert, 2005; McClure, Lankes, Gross, \& Choltco-Devlin, 2002; White, 2001), some methods from traditional reference (in person) evaluation are appealing for the evaluation of virtual reference as well. Thus, approaches used to evaluate traditional reference services will be discussed prior to the discussion of virtual reference service evaluations.

A major concern in the evaluation of reference services involves a discussion about the variables that should be measured. Evaluation of traditional reference services focused on the types of questions asked, the accuracy, completeness, and usefulness of the information provided by a reference librarian, on user satisfaction, and on the librarian's behavior (Gross \& Saxton, 2002). Saxton and Richardson (2002) developed the most comprehensive model of reference service for their multilevel analysis. Their model is based on the following independent predictors: query (difficulty, currency), user (library usage, reference service usage, and educational level), service behavior exhibited by the librarian (readiness, interest, understanding, and verification), librarian (experience, education level), library (collection size, service level, service policy); and on the following dependent outcomes: utility (usefulness, completeness), user satisfaction, and accuracy. Dewdney and Ross (1994) proposed the "willingness to return"

(Reference and User Services Association, 2004b). White (2001) defines virtual reference service as "an information access service in which people ask questions via electronic means (such as e-mail and Web forms). In turn knowledgeable individuals answer the questions, and responses are transmitted via electronic means" (p. 211). Thus, e-mail reference service is one type of virtual reference service. 
to the same librarian as a measure of reference effectiveness; they found that librarian's friendliness and understanding were correlated with user's overall satisfaction. Similarly, Saxton and Richardson (2002) found that the best predictor of user satisfaction was the librarian's behavior. It was therefore suggested that a predictor of a reference transaction's success can be attributed to the interaction between the user and the librarian (Gers \& Seward, 1985; Reference and User Services Association 2004a; Whitlatch, 1990). Using the user satisfaction measure in traditional reference evaluation studies repeatedly found higher levels of effectiveness than using the accuracy measure (Saxton, 2002). A common explanation given for the high satisfaction rates was that the librarian behavior rather than the accuracy or completeness of the answer affected user's evaluation.

Evaluations of virtual reference services utilize similar measures to those of traditional reference. For example, studies focused attention on the type of questions (e.g., Gilbert, Liu, Matoush, \& Whitlatch, 2006; King, Nichols, \& Padilla, 2006; Walter \& Mediavilla, 2005; Ward, 2005; White, 2001), accuracy, completeness, and usefulness of the service (e.g., Croft \& Eichenlaud, 2006; Fernandez, 2004; Gilbert, Liu, Matoush, \& Whitlatch, 2006; Pomerantz, Lou, \& McClure, 2006; Walter \& Mediavilla, 2005) and user satisfaction (e.g., Bobrowsky, Beck, \& Grant, 2005; Gilbert, Liu, Matoush, \& Whitlatch, 2006; Pomerantz, Lou, \& McClure, 2006; Ward, 2005).

Empirical studies of virtual reference transactions report variations in the level of effectiveness by question type (Kwon, 2007), by institution (Stacy-Bates, 2003), and by user name (Shachaf \& Horowitz, 2006). For example, Stacy-Bates (2003) reports variations among ARL institutions in the provisions of virtual reference services. Kwon (2007), for example, reports different levels of question answering effectiveness by request type in collaborative virtual reference services. Finally, Shachaf and Horowitz (2006) report different levels of service quality to Arabs and African Americans compared to Caucasian users. Using the knowledge that was gained from prior research about variations in the level of service quality by request type, institution, and user name the expectations in this study are that variations in adherence to professional guidelines may be found. This study aims to assess whether adherence to the two sets of professional guidelines would vary across institutions, users, and requests, and whether these variations would be similar for both sets of guidelines.

\section{Guidelines for virtual reference services}

Ronan, Reakes, and Cornwell (2003) describe the obstacles involved in the evaluation of online real-time reference; they claim that "the standards and guidelines for the reference profession are lagging behind the rapidly evolving world of online synchronous reference" ( $\mathrm{p}$. 227). In an effort to help librarians improve user-librarian interaction both in person and online, the Reference and User Services Association (2004a) published behavioral guidelines for reference librarians. These guidelines originally focused on traditional reference services, but were modified to include instructions for both in person and remote reference services. Similarly, the International Federation of Library Associations (2004) published another set of guidelines that focuses solely on digital reference and relies partially on the Reference and User Services Association's (2004a) guidelines. Both sets of guidelines are summarized in Tables 1 and 2.

These two sets of guidelines suggest (ideal) behaviors for librarians (International Federation of Library Associations, 2005; Reference and User Services Association, 2004a), assuming that adherence to these guidelines by professionals may result in a higher level of service. The guidelines also provide standard criteria that could be used for performance 
evaluation of reference services and individual librarians (Gatten \& Radcliff, 2001; Saxton \& Richardson, 2002). Thus, utilizing these guidelines to evaluate effectiveness, through an examination of the level of adherence of librarians to the professional guidelines, provides another way to systematically evaluate the quality of virtual reference services. It also allows for an objective and comparative measure of virtual reference service effectiveness across institutions.

A few evaluative studies of virtual reference services have utilized these guidelines (Kwon, 2004; 2006; Shachaf \& Horowitz, 2006; Walter \& Mediavilla, 2005; Ward, 2003; Zhuo, Love, Norwood, \& Massia, 2006). However, these studies lack a systematic and complete treatment of the guidelines; most of them refer only to RUSA guidelines and rely only on parts of the guidelines. These studies also report low levels of adherence to the guidelines. Kwon (2004), in her assessment of virtual reference services, found that the frequencies of the observed behaviors, which were recommended by RUSA as part of the behavioral guidelines, ranged from $28.7 \%$ to $63.7 \%$. Her findings support the low frequencies found in Ward's (2003) earlier analysis of virtual reference along the five behavioral areas of RUSA guidelines. These low levels of observed behaviors are remarkable even when considering the fact that different behaviors may not be relevant in answering certain types of requests (e.g., a copy of a book chapter) or when taking into account the fact that in virtual reference it is more difficult to project and observe these behaviors (e.g., approachability and interest). In particular, it is remarkable in light of Richardson's (2002, p. 41) argument that "reference is doing better than we [reference librarians and researchers] thought."

A systematic examination of the level of adherence to the two sets of standards would be beneficial; the need for such studies is clear especially due to the lacunae of empirical evaluation of virtual reference services in light of the standards. Thus, this paper aims to evaluate the extent of librarians' adherence to their professional guidelines and to serve as a benchmark for future evaluations. It uses these two sets of guidelines as standards for evaluation of virtual reference effectiveness, and therefore it focuses on behavior and outcome measures. The study also compares the level of adherence to each of the two sets of guidelines.

The appearance of the RUSA or IFLA behaviors is contingent on many different factors, such as the type of reference query, user type and name, and institutional policies. A query that simply requests the librarian to send a specific book chapter via an e-mail would typically involve neither search strategies (e.g., RUSA's Area 4) nor a reference interview (RUSA's Area 3 ). Similarly, this request (to send a book chapter) may involve adherence to specific institutional policies that would exclude this request from the scope of the service provided to user (i.e., the service does not make photocopies or scan book chapters and send them to users via snail mail or e-mail). Also, for this request, for example, an answer would not require some of the behaviors recommended in the guidelines, (e.g., asking what the user already tried, or suggesting narrower or broader topic). Thus, the level of adherence to the guidelines may vary across request types. Likewise, institutional policies or technological features that are integrated into the replies may affect the level of appearance of certain RUSA or IFLA behaviors. For example, policies about greeting and ending styles may vary across institutions (e.g, signing by name, departmental affiliation, and the provision of contact information). Likewise automatic features that include certain text in the librarian reply may vary across institutions (e.g., user request, greetings, and contact information). The level of adherence to the guidelines may thus vary across institutions. Finally, based on prior research (Shachaf \& Horowitz, 2006), there is a reason to believe that adherence to the guidelines may vary by user name. 
This paper evaluates the level of adherence to the two sets of guidelines (IFLA and RUSA), compares the guidelines, and examines the variations in level of adherence to the guidelines by user name, request type, and institutions. Specifically, this paper addresses the following research questions: 1 . What is the extent of adherence to RUSA guidelines and to IFLA guidelines in virtual reference services? 2. How does the level of adherence to RUSA guidelines or IFLA guidelines vary based on request type, user name, and institution? 3. Do outcomes measures of reference transactions (accuracy, completeness, and satisfaction) correlate with the level of adherence to RUSA or IFLA guidelines?

\section{Procedures}

Virtual reference service in this study refers to question answering services that libraries provide via e-mail, an asynchronous channel of communication, either through a mailto link on a library website or a web form that users can fill out to ask reference questions online. These requests are answered by library employees via e-mail. Thus, email reference service is one type of virtual reference service. While virtual reference enables service to be expanded to anywhere anytime, the asynchronous e-mail reference service involves several unique benefits and challenges. On the one hand, an asynchronous reference service allows librarians to answer requests on their own time, after having time to conduct all necessary research, which might enhance the replies' accuracy and completeness. On the other hand, the same asynchronous channel inhibits question clarification and lacks the non-verbal cues and synchronous feedback that are crucial for an effective reference interview, potentially inhibiting the effectiveness of the user-librarian interaction.

"A number of techniques have been developed to try to evaluate the effectiveness of reference transactions in any library. Methods include unobtrusive evaluation, obtrusive evaluation by user surveys, and other methods and compilation of reference statistics" (Bopp \& Smith, 2002, p. 253). Various methods and procedures for data collection are used in traditional reference service evaluations. For example, forms are used to generate librarians' evaluations of request types. Surveys of user satisfaction are utilized. Another method for data collection is the unobtrusive approach. While this methodology presents ethical challenges, such as the waste of library resources, the practice of deceiving librarians, and other complications, it bears higher external validity compared to the surveys and the forms mentioned above. For instance, unobtrusive methods can be in particular useful when sensitive variables are the focus of the study (Shachaf \& Horowitz, 2006).

Methods used for data collection in virtual reference evaluation mainly follow the same paths as in traditional reference. Forms and exit surveys are frequently utilized, as they are in traditional reference. However, data collection methods in virtual reference are enhanced by the ability to analyze transcripts of reference transactions. Utilizing transcripts (e.g., Bobrowsky, Beck, \& Grant, 2005; Fagan \& Desai, 2003; Fernandez, 2004; Gilbert, Liu, Matoush, \& Whitlatch, 2006; King, Nichols, \& Padilla, 2006; Kwon, 2007; Pomerantz, Lou, \& McClure, 2006; Radford, 2006; Walter \& Mediavilla, 2005; White, 2001) for analysis is as common as the use of survey data (e.g., Bobrowsky, Beck, \& Grant, 2005; Croft \& Eichenlaud, 2006; Cummings, Cummings, \& Frederikson, 2007; Gilbert, Liu, Matoush, \& Whitlatch, 2006; King, Nichols, \& Padilla, 2006; Kwon, 2007; Pomerantz, Lou, \& McClure, 2006; Ward, 2005; White, 2001).

Whitlatch $(1989 ; 2001)$ emphasized that the unobtrusive method can also be used effectively for virtual reference evaluation. Following this suggestion a number of evaluation 
studies of virtual reference services employed this method (Arnold \& Kaske, 2005; Carter \& Janes, 2000; Kaske \& Arnold, 2002; Shachaf \& Horowitz, 2006; Stacy- Bates, 2003; Ward, 2003). Kaske and Arnold (2002) conducted one of the first unobtrusive studies of virtual reference and found a 55\% accuracy rate in chat sessions. Their findings echo the findings from Hernon and McClure's (1986) classic unobtrusive study, which found that librarians' responses are accurate only $55 \%$ of time. In another unobtrusive study, which examined virtual reference transactions using response completeness rate as an indication of success, Ward (2004) found that $47 \%$ of the transactions provide complete answers, and $32 \%$ were mostly complete (79\% completeness rate when the two categories, complete and mostly complete, are combined). Similarly, Arnold and Kaske (2005) evaluated chat reference transactions at the University of Maryland College Park and found that $92 \%$ of the requests were answered correctly (but only $38 \%$ correctly and completely with references cited). They concluded, echoing Richardson (2002), that reference librarians are doing better than we [practitioners, administrators, and researchers] thought (Arnold \& Kaske, 2005); they argue that librarians are achieving higher levels of correct and complete transactions in answering virtual reference requests than previously was found in evaluations of reference services (Arnold \& Kaske, 2005). Other unobtrusive studies of virtual reference services focused on policies and services to unaffiliated students (Stacy- Bates, 2003) and equality of services across different user groups (Shachaf \& Horowitz, 2006).

Like several studies that report findings from unobtrusive evaluations of virtual reference services (Carter \& Janes, 2000; Kaske \& Arnold, 2002; Shachaf \& Horowitz, 2006; Stacy-Bates, 2003), this study applied an unobtrusive method, where responses to queries are assessed without the reference service providers knowing that they are being studied. Because one of the limitations of the unobtrusive method is that it involves a waste of resources (librarians' time and attention answering requests not sent by their intended patrons), we made an effort to minimize the time spent answering our questions by designing the questions so that the librarians would not have to spend much time on them. In spite of its limitations, "the method has become increasingly accepted. It is by far the most-used methodology for evaluating services today" (Katz, 2002, p. 199). Despite the ethical concerns involved with this method, it was used here because it is possible that if librarians know that they are being observed, they will act differently.

This study used data that were collected unobtrusively in 2005-2006 from 54 academic libraries in North America. Using The Carnegie Classification of Institutions of Higher Education (The Carnegie Foundation for the Advancement of Teaching, 2000) all Doctoral/Research universities-extensive and Doctoral/Research universities-intensive university libraries (253 libraries in all) were invited, by an e-mail sent to the head of the reference department, to participate in a study. Many of the libraries declined participation due to institutional barriers or because their services are part of consortial virtual reference. Fifty-four libraries agreed to take part in the study (16\% participation rate).

A total of 324 queries were sent by the researchers to these 54 libraries. Using six fictitious names with six different hotmail e-mail accounts, the researchers sent six different requests to each of these libraries using the counterbalanced method to avoid variables confounding. The technique in counterbalancing is to make sure that each user name appears in each position (institution and question type) an equal number of times. Each library received only one request from each user, and each library received a specific type of request only once. During six consecutive weeks, either during the fall semester of 2005 or during the spring 
semester of 2006, a library received one request per week with a different question from a different user.

Because we wanted to be able to send six requests to each institution but not to have them sent by the same user to assure the unobtrusive nature of the study, we used six users in the design of this study. Each user name represents ethnic and/or religious group identity: Mary Anderson (Caucasian, Christian), Moshe Cohen (Caucasian, Jewish), Ahmed Ibrahim (Arab), Latoya Johnson (African American), Rosa Manuz (Hispanic), and Chang Su (Asian). We had good reasons to believe that adherence to the guidelines will vary by user name, because Shachaf and Horowitz (2006) report that service quality in e-mail reference varied across these six user names.

Since adherence to policies may vary by request type, six different requests were included as part of the study design. Half of the requests, questions 1-3, are expected to be answered, while the other half, questions 4-6, are not expected to be answered by the reference librarians. These requests were designed, based on prior research (Stacy-Bates, 2003), so that three of them would be answered and the other three would fall outside the scope of most academic institution policies and would not be answered. The first three requests (1-3) followed Stacy-Bates's (2003, p. 61) reference queries, which according to her findings are expected to be answered by more than $90 \%$ of the libraries. The next three requests (4-6) were not expected to get an answer, but either a referral or an explanation of institutional policies. It was assumed that unaffiliated users will not receive answers to topical requests because of institutional policies that limit services by question type and by user status (Stacy-Bates, 2003; Tunon, Barsun, \& Ramiraz, 2004). In addition, it was assumed that a full text article will not be sent to an affiliated user who requests it due to licensing restrictions on databases' terms of use (e.g., Emery, 2005). In a way question 5 , and to a certain extent also question 6 , invite the librarian to act illegally by sharing electronic resources with unauthorized users. The article that was selected for the fifth question was available via EBSCO Academic Search Premier, and it was assumed that any of the academic libraries in this study will have access to the fulltext of this article, but that due to licensing restrictions librarians will be less likely to send the full text of the article. The same issues apply to the sixth question; since The Elements of Style is a commonly required college text, librarians would likely have access to it (WorldCat indicates that all the libraries in our sample had a copy of this book), but would be unlikely to provide an electronic copy to the user. These are the queries that were sent:

1. Dissertation query (Stacy-Bates, 2003): Can you tell me the title of [name]'s dissertation? [She/He] finished [his/her] degree at [institution name] in [year]. Do you have it in your library? How can I obtain a copy of this dissertation?

2. Sports team query (Stacy-Bates, 2003): How did [sports team name] become the name for [institution name]'s sports teams? Can you refer me to a book or article that discusses it?

3. Population query (Stacy-Bates, 2003): Could you tell me the population of [institution's city name] in 1963 and 1993?

4. Subject query: Could you help me find information about [special collection topic]? Can you send me copies of articles on this topic?

5. Article query: Can you send me by e-mail a copy of the article "Free Indirect Discourse and Narrative Authority in Emma" by D.P. Gunn?

6. Could you please send me a pdf copy of pp. 66-69 (ch.V) from Strunk and 


\section{White's The Elements of Style? ${ }^{2}$}

Before the questions were sent information about each institution was collected and saved in a file. This information was later used when preparing questions 1,2,3, and 4, which ask about information unique to the institution. Each institution file included, in addition to the institution name and location:

- Details of a dissertation that was awarded by the institution in 1964 (or the earliest date thereafter) which was identified using Dissertation Abstracts.

- Sports team's name as identified from a search on the parent institution website.

- The city in which the institution is located, as identified from the address on the institution's website.

- Topics of special collections for the subject query.

- Policies about service restrictions for unaffiliated users and response time.

\section{Data Analysis}

All 324 queries were uploaded into Nvivo2.0 to facilitate content analysis and the search for frequencies and co-occurrences of codes and attributes. Nvivo is a software that is designed to facilitate qualitative analysis. Nvivo matrix capabilities facilitate the identification of patterns among categories and also between categories and attributes.

First a coding scheme was developed based on each of the sets of guidelines. A new coding scheme was developed for the analysis of the 324 transactions in this study because of inconsistent interpretations and incomplete analysis found in the available studies that utilized these guidelines (Kwon, 2004; 2006; Shachaf \& Horowitz, 2006; Ward, 2003; Zhuo, Love, Nrwood, \& Massia, 2006). Two independent coding schemes were created, one for each of the sets of guidelines.

IFLA guidelines include two main sections (International Federation of Library Associations, 2005). The first section discusses the administration of digital reference services and was written with the responsibilities of the program administrator in mind. This section is not applicable for meaningful analysis of individual reference transactions since it is likely constant for all the transactions processed by one institution. The second section discusses the practice of digital reference services and provides guidance for practitioners. This section provides standards of practice to facilitate collaborative work. It provides guidelines that focus mainly on "answer formulation", which is one of the five steps of the digital reference model (Pomerantz, Nicholson, Belanger, \& Lankes, 2004). Table 1 presents the coding scheme that has been developed from IFLA guidelines (International Federation of Library Associations, 2005).

Insert Table 1 approximately here

RUSA behavioral guidelines include five main areas: approachability, interest, listening/ inquiring, searching, and follow up (Reference and User Services Association, 2004a). Each of the five areas has three sections: general, in person, and remote. The general guidelines can be applied to any type of reference interaction while the other two sections are specific to either in person service or remote service (e.g., telephone, e-mail, and chat). The coding scheme relies mainly on the general and the remote sections, but it also includes codes that are based on the in

\footnotetext{
${ }^{2}$ This question was used only during Spring 2006 and was therefore sent only to 31 out of the 54 libraries.
} 
person sections when the recommended behaviors could also be observed in the context of remote service. Table 2 presents the coding scheme that has been developed based on RUSA guidelines for behavioral performance of reference and information service providers (Reference and User Services Association, 2004a).

Insert Table 2

The coding for each of two sets of guidelines was independent from the other; each set of guidelines was coded in a separate Nvivo project. Each transaction was classified according to a total of 34 codes for RUSA and 33 for IFLA, as well as 12 attributes for the RUSA guidelines and 10 attributes $^{3}$ for the IFLA guidelines (Tables 1, 2, and 3). The two coding schemes, which resulted from the two sets of guidelines, share only $25 \%$ of the codes and differ greatly from each other. The codes that appear in both coding schemes include: accurate answer, concluding remarks, greeting/hello, greeting/with honorific, objective behavior, provide response time, referral to the library for further help, search strategies explained, thank the user for using the service. Attributes that were used include: user name, institution name, question type, semester, adherence to turnaround policies, response time, length of reply, automatic response, and satisfaction (Table 3). Each attribute had multiple values that represent the variability of the attribute across all transactions.

Insert Table 3

After all the transactions were coded by one coder $10 \%$ of the data were coded by a second coder to evaluate the level of inter-coder reliability. The coding was followed by a discussion among the coders that clarified codes and modified the coding scheme. Coding by the two coders was required until an acceptable level of agreement between the two coders was reached (above 90\%) for each of the two sets of guidelines. The final result of the inter-coder reliability (number of agreements divided by the sum of number of agreements and disagreement) was 92\%, Cohen's Kappa was .787.

While both sets of guidelines and most of the codes focus attention on thelibrarians-user interaction, there are several outcome measures that are indicative of reference effectiveness: accuracy, completeness, and user satisfaction. Saxton and Richardson's (2002) model of reference effectiveness includes three outcome measures: accuracy, satisfaction, and utility (utility includes completeness and usefulness). In our study we used accuracy, user satisfaction, and completeness (as part of utility) due to the challenges involved in assessing utility for our information need scenarios. Two of these three outcome measures are mentioned by RUSA and IFLA guidelines: accuracy (in both sets of guidelines), and completeness (only in IFLA guidelines). The guidelines assume that the user-librarians interaction precedes the outcomes and to a certain extent can predict transaction's effectiveness (RUSA, 2004a). However, outcome

\footnotetext{
3 The difference between attributes and codes is that a code refers to a section in the transaction text, while an attribute is a descriptive feature that is not part of the text of transactions. The values of attributes can be assigned to transactions without the need to perform content analysis of the text, while a code is assigned to a specific section of the text in the transaction. For example, "greeting" the patron is a code while "response time" or "request type" are attributes.
} 
measures indicate the effectiveness of the reference transactions. In this study we designed, based on the guidelines and the literature review, three outcome measures: 1) satisfaction, 2) accuracy, and 3) completeness.

Satisfaction was evaluated by eight independent coders who coded transactions for their perceived level of satisfaction. Using this method for evaluating satisfaction of reference services by proxies is based on the extensive use of scenarios in satisfaction research (Alford \& Sherrell, 1996; Bitner, 1990; Churchill \& Surprenant, 1983; Ueltschy, Laroche, Tamilia, \& Yannopoulosd, 2004). The scenarios needed to be (1) ones that were familiar and (2) realistic (Ueltschy et al., 2004). The scenarios are presented to coders who are asked to imagine themselves in a setting and to report how they would "feel" about the service encounter using a satisfaction scale.

The coders were graduate students who had completed one year of study toward an MLS degree but had no prior experience with reference work. All identifiable information was removed from the transactions (e-mail addresses, user name, librarian name, institution name, mascot name, and town name from the population question). Each transaction was coded by three independent coders. Each coder coded 120 transactions from all six types of questions. A three point Likert Scale (good, 3; fair, 2; poor, 1) was used to code each transaction. Once all transactions had received at least three independent evaluative scores, mean scores were calculated for each transaction.

The second evaluation of effectiveness was based on accuracy. Accuracy was evaluated for the answers to the dissertation and population questions. The dissertation answer was evaluated by comparing the title obtained from Dissertation Abstracts with that provided by the library. The population answer was checked either by comparing the data given with the data from the source the librarian had cited, or the data from the United States census where no citation was provided. Only these two requests were included because accuracy could be rigorously and meaningfully evaluated for each of these 2 requests but not for the other 4 requests. For requests 5 and 6 the accuracy measure was not a relevant measure, because the user requested a photocopy of an article or of a book chapter.

Completeness of transactions was also coded. A transaction was coded as complete only when all parts of a multi-part question had been answered, i.e., providing both the name of the university's sports team and a source where the user could get further information on the topic (for the sports team request), or when the specific task requested had been performed, i.e., sending the requested article as opposed to telling the user how to find it (for the article request). However, because there is a conflict between completeness and licensing compliance for requests 5 and 6 , interpretations of the completeness frequencies for these codes should be made with caution. A high frequency of complete answers to these requests means that the librarians did not comply with licensing restrictions, and for that reason it is not desired. However, low frequencies for these codes should not be interpreted at face value as a better outcome measure because the low frequencies also include cases when the user received no answer.

Similarly, additional challenges emerged with the operationalization of the two sets of guidelines into coding schemes, and with coding and interpreting the frequencies; these involve several limitations of the study. For example, using an honorific to address the user in e-mail reference indicates respect and courtesy (Tables 1,2). However, the lack of honorific cannot mean at face value a lack of respect because it is possible that the librarian did not have enough information to identify the user, and thus tried to avoid misusing an honorific. Using an honorific cannot be uniformly applied, because if the user does not provide the honorific, the librarian 
would have to guess, thus alienating many users by mistakes in rank, title, degree, gender, and/or marital status and providing bad service where good service was intended. In this study, the librarians who address Ahmed Ibrahim and Chang Su had to face these challenges and used honorifics less frequently than with these users, perhaps in an effort to avoid misuse of the honorific. In both cases the first and last name of these users could be exchanged; also, in the Asian convention of writing names the last name precedes the first name, and the librarian would not be able to tell if the user used the American or the Asian convention. Another example of the difficulty of operationalization comes from avoiding using Internet abbreviations (Table 1), which can seem stilted if the user employs them and is obviously comfortable in the online environment. In this study, our user requests did not include library jargon or internet acronyms, but this might be a more challenging issue in real transactions, and in particular chat transactions. The choice of the standards to lump speaking the language of the medium (internet acronyms) together with Library jargon (MARC, DDC, etc.) is unfortunate. While the guidelines are problematic, their utilization in this study was not challenged because the requests provide no indication that the user is familiar with internet acronyms or library jargon; the librarian should not have used them.

Once all transactions had been coded, Nvivo search and retrieve capabilities were utilized to generate frequencies for each code and co-occurrence capabilities were used to generate matrices of codes by user name, institution, and request type. Finally, correlations among the three outcome measures were calculated using SPSS 13.0.

\section{Findings}

\section{Adherence to IFLA and RUSA guidelines}

This section addresses the first research question: what is the extent of adherence to RUSA guidelines and to IFLA guidelines in virtual reference services? First the level of adherence to IFLA guidelines is reported and then adherence to RUSA guidelines is reported.

Table 4 reports the frequencies of codes that indicate adherence to IFLA guidelines in the 324 transactions. The frequent codes involve answer completeness and accuracy (calculated only for two out of the six questions), as well as behaviors, such as including greetings and closure, messages that are well structured, and messages that are written in a clear, objective, and appropriate manner. More specifically, the highest level of adherence to IFLA guidelines (Table 4 ), are evident in the following codes: objective behavior (90.4\%) and clarity of response (90.4\%). Other frequent codes are those that indicate answer accuracy (72\%) and completeness (complete answer to the dissertation question, $75.8 \%$, and to the population question, $68.9 \%$ ), following time policy (62\%), as well as codes such as greetings (hello, 50.6\%), closure (name of librarian, 63.2\%; department, 62.6\%), appropriate length and level (64.5\%), and including heading, body, and closure $(62.3 \%)$.

Insert Table 4

The lowest level of adherence to IFLA guidelines involves codes that were observed in less than $50 \%$ of the transactions. Many of the codes that are indicative of professional behavior have low frequencies. These include, for example, explaining search strategies $(8.3 \%)$, including evaluative remarks $(0.6 \%)$, concluding remarks $(46.9 \%)$, and thank you for using the service 
(29.6\%). In addition, automatic responses were sent only for $26.7 \%$ of the requests (in other words, approximately one fourth of the institutions sent automatic responses).

Insert Table 5

As can be seen in Table 5, which indicates adherence to RUSA guidelines, the most frequent codes involve written style (appropriate written language, 92.9\%; objective response, $91.9 \%$ ), followed by availability of policies (policies made public, $82.4 \%$; include question scope, $57.4 \%$; include turnaround time, $71.2 \%$ ), easy access to the service (two clicks or less from the library home page, $83 \%$ ), and the use of webforms (94.4\%). Similar to the case of adherence to the IFLA guidelines, adherence to RUSA guidelines involves high frequency of greetings (50.6\%), and closure (name of librarian, $63.8 \%$; department name, $62.6 \%$ ), as well as answer accuracy $(72 \%)$.

Lower levels of adherence to RUSA guidelines are observed in addressing the user by using first name (37.6\%), thanking the user for using the service (29.6\%), including concluding remarks (46.9\%), and making follow up remarks (28\%). Other less frequent codes involve providing detailed information on the resources (34.8\%), rephrasing the question $(9.5 \%)$, explaining search strategies $(8.6 \%$ ), asking for additional information (open questions, $0.9 \%$; closed questions, $3.7 \%$ ), asking what the user already tried ( $0.6 \%)$, and suggesting a broader or narrower topic (13.5\% for the topical questions only).

\section{Variations in adherence to IFLA and RUSA guidelines by request type, user name, and institution}

This section addresses the second research question: how does the level of adherence to RUSA guidelines or IFLA guidelines vary based on request type, user name, and institution? First it indicates adherence to IFLA and RUSA guidelines by user name (Tables 6, 7; Figure 1), then by institution (Table 8; Figure 2), and finally by request type (Tables 9, 10; Figure 3 ).

Insert Tables 6 and 7.

Insert Figure 1.

The difference in frequencies of codes by user name is apparent when using either set of guidelines for evaluation (Figure 1). Despite the fact that the total frequencies of codes by RUSA guidelines are slightly higher for five of the six users the pattern of differences among the users does not differ between the two sets of guidelines and the differences between Ahmed and Rosa (for example) are only intensified when IFLA guidelines are utilized (Figure 1). For example, while Rosa is getting replies with the highest frequencies (566 - IFLA and 565 - RUSA), replies to Ahmed have the lowest frequencies (452 - IFLA and 479 - RUSA). A similar pattern is evident in the frequencies of most of IFLA (Table 6) and RUSA (Table 7) codes. As can be seen in Table 6, Ahmed is less frequently addressed with Hello (24) compared to Rosa (33) and receives fewer follow up remarks (12) compared to Rosa (21). The librarian is less likely to sign her reply by name or to provide contact information in messages that Ahmed (31 name and 12 contact information) or Moshe (29 name and 12 contact information) receive, while in messages 
that Rosa receives these are more frequently used (42 name and 22 contact information). The frequency of objective behavior (Ahmed and Moshe 47 each, and Rosa 52) and the inclusion of authoritative sources (Ahmed 18 and Rosa 27) repeat this pattern (Table 6). Moreover, Rosa (17), Mary (17), and Chang (16) receive accurate answers more frequently than Ahmed (11), Moshe (12), or Latoya (13) and the librarian thanked the user for using the service more frequently in messages sent to Rosa (20) than to Ahmed (12).

These differences were checked for statistical significance, and these differences, except for one, were found not to be significant across the six users. Two way contingency tables analyses were conducted to evaluate whether the inclusion of the librarian's name, department name, or contact information was different among users. Librarian's name and users were found not to be significantly related, Pearson $\chi 2(5, \mathrm{~N}=324)=8.348, \mathrm{p}=.138$, Cramer's $\mathrm{V}=.158$. Department name and users were found not to be significantly related, Pearson $\chi^{2}(5, \mathrm{~N}=324)=$ $2.156, \mathrm{p}=.827$, Cramer's $\mathrm{V}=.082$. Contact information and users were found not to be significantly related, Pearson $\chi 2(5, \mathrm{~N}=324)=6.254, \mathrm{p}=.282$, Cramer's $\mathrm{V}=.139$. There are no significant differences among different user groups. Further, two way contingency tables analyses were conducted to evaluate whether the completeness of the responses was different among users, and whether the accuracy of the responses was different among users. Completeness and users were found not to be significantly related, Pearson $\chi^{2}(5, \mathrm{~N}=324)=$ $1.533, \mathrm{p}=.909$, Cramer's $\mathrm{V}=.076$. Accuracy and users were found not to be significantly related, Pearson $\chi 2(5, \mathrm{~N}=324)=3.356, \mathrm{p}=.645$, Cramer's $\mathrm{V}=.102$. All users were treated equally in terms of completeness and accuracy of the responses.

Finally, a two way contingency table analysis was conducted to evaluate whether the use of first name in the response was different among users. Use of first name and users were found to be significantly related, Pearson $\chi 2(5, \mathrm{~N}=324)=13.831, \mathrm{p}=.017$, Cramer's $\mathrm{V}=.207$. Follow-up pairwise comparisons were made to evaluate the differences among users. The Tukey's HSD method was used to control for type I error at the .05 level across all six comparisons. The significant pairwise differences were between Chang Su and all other users. A two way contingency table analysis was conducted to evaluate whether the use of hello in the response was different among users. Use of hello and users were found not to be significantly related, Pearson $\chi^{2}(5, \mathrm{~N}=324)=3.956, \mathrm{p}=.556$, Cramer's $\mathrm{V}=.11$. The frequencies for full name and honorifics per cell were less than five for some users; cross-tabulation in these cases could not be meaningful and therefore was not conducted. It should be emphasized that the frequencies show that Mary is addressed with honorific twice as many times than Moshe, Latoya, Ahmed, or Chang. Also, Chang Su is never addressed with an honorific and is addressed much less frequently by first name than other users, but instead is addressed much more by full name. Traditionally, Chinese names place the surname before the given name, which may make it more difficult to distinguish between the two. For that reason it is possible that librarians are confused about Chinese first names and address Chang Su by full name in order to cope with this confusion. Thus the ways in which librarians address different users vary, but this variation is not statistically significant and does not indicate inequality in the level of service provided.

Insert Table 8.

Insert Figure 2. 
Table 8 provides the total frequencies of adherence to RUSA and IFLA guidelines by institution (Figure 2). Unlike the variations among users, which maintained a similar pattern of adherence to the two sets of guidelines, institution ranking varied based on the set of guidelines that was utilized in the evaluation. For example, the ranking of the top 5 institutions by IFLA guidelines includes: $35,17,43,8$, and 18 , while the ranking of the top 5 institutions by the RUSA guidelines includes: 27, 53, 23, 12, and 4 (tie with 24). None of the best performing institutions appears on both lists of the five top performing universities.

Insert Tables 9 and 10.

Insert Figure 3.

The frequencies of adherence to IFLA and RUSA guidelines by request type are similar in that the differences between the guidelines are minimal for the dissertation, mascot, and population questions but much more noticeable for the topical, article, and book questions (Figure 3). Some variations between the two sets are due to codes that appear only in one set of guidelines and not in the other. This includes, for example, the codes for answer completeness that appear only in IFLA guidelines (Table 9). Complete answers were provided most frequently for the dissertation ( $76 \%$ of these requests) and population requests ( $71 \%$ of these requests), but much less frequently for the mascot request (24\% of these requests). Answer accuracy appears in both sets of guidelines and the results indicate that more accurate answers were provided for the dissertation questions (52) than for the population requests (36) (Tables 9 and 10). Further, instructions on how to use a database were provided for the article request (33\% of these requests) and rarely for any other type of requests. Search strategies (IFLA and RUSA) were also explained more frequently for this type of request (17\%), perhaps because the librarians could not send the article to the user, but still tried to help as best they could, by explaining how to search for the full text of the article. The user was referred to the library for further assistance (IFLA and RUSA) more frequently in answers for the topical requests (17\% of these requests). As can be expected, in answers to the topical requests the librarians asked more open questions and suggested broader or narrower topics (RUSA). In answers for the mascot request compared to answers for the article request, the closure of the reply includes more contact information ( 24 compared to 11; IFLA), concluding remarks (30 compared to 21; IFLA and RUSA), name of librarian (47 compared to 35: IFLA); in addition the librarian thanked the user for using the service (IFLA and RUSA) more often (19 compared to 16) in the mascot reply compared to the article reply.

Insert Table 11.

While 201 (62\%) answers adhere to time policies (IFLA), in 28 (9\%) cases the replies did not reach the user on time, and $95(29 \%)$ of the requests were not answered at all. Adherence to time policies for requests that were sent on weekdays is higher than for requests that were sent over the weekend. It is twice as likely that an institution will not adhere to its time policy over the weekend. Thirty three percent of the requests that were sent over the weekend compared to $17.5 \%$ of the requests that were sent on weekdays were not answered on time (Table 11). 


\section{Transaction outcomes}

This section addresses the third research question, do outcomes measures of reference transactions (accuracy, completeness, and satisfaction) correlate with the level of adherence to RUSA or IFLA guidelines? First this section reports on transaction outcomes; it reports the total results of three outcome measures: accuracy, completeness, and satisfaction. Next, this section reports correlations between the outcomes measures and the adherence to IFLA and RUSA guidelines by institution.

Accuracy is an outcome measure that is mentioned in both sets of guidelines. Seventy two percent of the (dissertation and populations request) transactions were answered accurately. Providing a complete answer is another important indicator of good transaction outcome, but answer completeness is only mentioned by the IFLA guidelines (Table 4). Completeness rate is influenced by question type; the highest rate of completeness is found for the dissertation request. Seventy five percent of the responses to the dissertation request were complete, $22 \%$ of the responses were partial, and a few requests were not answered at all. The completeness rate for the population request was $68.9 \%$, and for the Mascot request it was only $25 \%$. Both the article request and the book chapter request were rarely completely answered $(15.7 \%$ for the article requests; $3.5 \%$ for the book chapter), and none of the topical requests were completely answered. However, because there is a conflict between completeness and licensing compliance for the article and book chapter requests, interpretations of the completeness frequencies for these codes should be made with caution. Neither a score opposite of that which would usually be desired nor low percentages are good indicators of the desired outcomes of completeness level by themselves. Furthermore, the lack of completeness for topical requests is due to the "can you send me copies of articles..." part of the request, something which never occurred. Most of the answers to the topical question instead included an explanation of how to search for the information requested or suggested articles and books. Thus, a simple interpretation of the completeness rate for these requests is not advisable.

Insert Table 12.

The third outcome measure, satisfaction from the reference transactions, is based on three independent evaluators for each transaction. The satisfaction level across all transactions on a scale of 1-3 (good, 3; fair, 2; poor, 1) was fair and the mean was $\mathrm{M}=2.24$ ( $\mathrm{SD}=.26$ ). The mean satisfaction level for transactions by user name from the highest to the lowest are: Rosa $(\mathrm{M}=$ $2.35)$, Chang $(\mathrm{M}=2.35)$, Mary $(\mathrm{M}=2.30)$, Latoya $(\mathrm{M}=2.22)$, Ahmed $(\mathrm{M}=2.20)$, and Moshe $(\mathrm{M}=2.17)$. The mean satisfaction level by type of request from the highest to the lowest is: population ( $\mathrm{M}=2.36)$, topical $(\mathrm{M}=2.34)$, book, $(\mathrm{M}=2.32)$, article $(\mathrm{M}=2.31)$, $\operatorname{mascot}(\mathrm{M}=$ $2.23)$, and dissertation $(\mathrm{M}=2.14)$. This rank does not seem to correlate with the completeness rates rank of the requests (completeness rate from highest to lowest: dissertation, population, mascot, article, book, and subject). The average satisfaction level by institution ranges from 2.8 to 1.8 per institution (Table 12). Further, based on the mean level of satisfaction, an institution's ranking varies from their ranking on both the IFLA or RUSA guidelines ranking. The top five institutions ranked according to the level of satisfaction are $36,54,9,44$, and 5 . The top five according to the adherence to IFLA guidelines raking are $35,17,43,8$, and 18 , while the top five on the adherence to RUSA guidelines are $27,53,23,12$, and 4 . There is not a single institution that is ranked in the top five in more than one ranking. 
Insert Table 13.

Pearson product-moment correlations were calculated for the outcome measures per institution (Table 13). The findings indicate significant correlations at $p=.05$ for: 1 ) adherence to IFLA guidelines and RUSA guidelines were significantly correlated $r=.697$; and 2) Adherence to IFLA guidelines and completeness were significantly correlated $r=.392$. The level of user satisfaction and adherence to RUSA or IFLA guidelines do not significantly correlate with each other.

\section{Discussion}

Service policies and performance guidelines are set with the intention to improve effectiveness levels. These guidelines are "[i]ntended to be used in the training, development, and/or evaluation of library professionals and staff, the Guidelines have subsequently been favorably evaluated by the profession, and currently enjoy widespread acceptance as standards for the measurement of effective reference transactions" (Reference and User Services Association, 2004a). Accordingly, libraries that aim at a high level of service should provide service that corresponds with a high level of adherence to the guidelines. Identifying the extent of adherence to the guidelines is therefore a critical practice that can facilitate benchmark studies. A library's level of adherence to the guidelines could be objectively compared to another library's if both use the same evaluation standards.

Two sets of guidelines (IFLA and RUSA) have been utilized for the evaluations in this study. Although the two sets of guidelines involve many similar standards, each of them includes unique components. The coding schemes that were developed and utilized in this study indicate that only $25 \%$ of the codes were common to the two sets. The codes that appear in both coding schemes include: accurate answer, concluding remarks, hello, used honorific, objective behavior, provide response time, referral to the library for further help, search strategies explained, thanked the user for using the service. The appearance of the codes in both guidelines indicates a high consensus that these should be performed. One would expect that these behaviors should be frequently observed, but the frequencies of these codes indicate that six out of the nine (shared) codes were observed in less than half of the transactions (concluding remarks, hello, used honorific, referral to the library for further help, search strategies explained, thanked the user for using the service).

\section{The extent of adherence to RUSA and IFLA guidelines}

This study found overall low levels of adherence to both set of guidelines. Except for objective behavior and clarity of writing (both sets of guidelines), which were observed in at least $90 \%$ of the transactions, most other behaviors were less frequent. Behaviors that were observed in more than $70 \%$ of the transactions involve accuracy and completeness (of responses to the dissertation request). While accuracy was specified in both sets of guidelines, completeness was specified only by the IFLA guidelines.

Other codes that were relatively frequently observed (more than $70 \%$ of the transactions) involve: the availability of policies, use of web-forms, and the accessibility of the service within two clicks from the library homepage. These codes, which are only suggested by RUSA guidelines, are based on an institution wide implementation of the guidelines and do not indicate behaviors of individual librarians which may vary at the transaction level. It may be that the 
relatively higher frequency of each of these codes is the result of the fact that most institutions adhere to them and subsequently it applies to most of the transactions.

Codes that indicate frequently observed behaviors in at least $50 \%$ of the transactions involve indications of the librarian's courtesy (both in RUSA and IFLA guidelines), appropriate structure, level and length of reply, and adherence to time policy (IFLA guidelines only). Much less frequently observed behaviors (in less than $50 \%$ of the transactions) are those that require the implementation of professional knowledge of conducting an effective reference interview. These include instances when the librarian explained the search strategy (IFLA and RUSA), rephrased the question (RUSA), asked for more information (RUSA), asked what the user had already tried (RUSA), included evaluative remarks (IFLA), made follow up remarks (RUSA), made concluding remarks (IFLA and RUSA), or thanked the user (IFLA and RUSA). While it is possible that these behaviors may be rarely observed both in virtual and traditional reference services, it is also possible that the low frequencies are unique to e-mail transactions. These low levels of observed behaviors concur with previous studies that examined the librarians' behavior when providing virtual reference services (Kwon, 2004; Ward, 2003). Yet, it should be stressed that the interpretations of the low frequencies for some of the codes should be made with caution. As stated earlier, the appearance of the RUSA and IFLA behaviors is contingent on many different factors, such as the type of reference query and institutional policies, to name a few. For example, search strategies, which appeared in only $8.3 \%$ of all transactions, are not expected to be included in all transactions (e.g., requests 5 and 6). Likewise, for these types of request, for example, an answer would not require some of the behaviors recommended in the guidelines, (e.g., asking what the user already tried, or suggesting a narrower or broader topic). Thus the lower frequencies of these specific codes should only be examined in light of the specific requests. However, most of the codes that have low frequencies (e.g., the librarian made follow up remarks, made concluding remarks, or thanked the user) could be expected to be more frequently observed.

\section{Variations by user name, institution, and request}

Shachaf and Horowitz (2006) indicate variations in the level of virtual reference service provided to users from different ethnic and religious backgrounds. In this study librarians adhere more to their professional guidelines (IFLA and RUSA) in replies they sent to Rosa compared to the replies to Ahmed. This trend of higher level of service to Rosa than to Ahmed is also evident in specific behaviors that are included in RUSA and IFLA guidelines and echoes the trends in Shachaf and Horowitz's (2006) findings. Yet, these differences were not found to be statistically significance across all six users.

Comparing only Rosa to Ahmed would be statistically significant, yet, this study involved six users for whom the frequencies of codes are spread in-between the two extremes and blur this difference. Librarians, like other service providers, aim to provide equitable service to all users, but are subject to their own subjective biases. It is possible that in the virtual environment these tendencies are intensified one way or another. This study identified that an institution's ranking based on adherence to one set of guidelines varies from its ranking based on another set of guidelines. None of the top ranked institutions based on adherence to the IFLA guidelines appeared to perform highly on adherence to RUSA guidelines. Further, the distance between ranks in the two guidelines can be large, as shown by the fact that in one instance an institution ranked 2 nd on one guideline ranking but 29th on the other. Variations in adherence to both RUSA and IFLA guidelines by user name, institution, and request type exist. While the 
variations by user name and by request type follow a similar pattern for adherence to both the RUSA and IFLA guidelines, the variations by institutions do not correspond when different sets of guidelines are utilized. The differences by user name and by request type were apparent when using IFLA guidelines more than when RUSA guidelines were used. Although the total frequencies of codes based on IFLA guidelines were lower than RUSA, the differences by user name and by request type were more clearly presented on the charts with IFLA frequencies than with the RUSA frequencies.

\section{Outcome measures and adherence to RUSA or IFLA guidelines}

This study found that the level of satisfaction varies among users, by institution, and by request type. The highest level of satisfaction among the users was assigned to messages that Rosa received. This is not a complete surprise given the fact that librarians adhere to both RUSA and IFLA guidelines more when responding to Rosa than to any other user. On the lowest end of the satisfaction range are the responses to Moshe and Ahmed. This, again, is in alignment with the level of adherence to both guidelines. While it was already suggested that virtual reference services are not equally provided to different user groups by Shachaf and Horowitz (2006), they assumed that the transaction's outcomes correlates with the reference librarian's behavior. This study has not made such an assumption and evaluated the satisfaction level as an outcome measures. As for accuracy and completeness, following the same pattern, Rosa received the highest level of complete and accurate responses and Ahmed the lowest.

This study found that the level of satisfaction associated with an institution's transactions was not correlated with its level of response accuracy and completeness. Further, the level of user satisfaction and adherence to RUSA or IFLA guidelines do not significantly correlate with each other. This is not in alignment with previous research that triggered the specific behaviors recommended by RUSA guidelines (Dewdney \& Ross, 1944; Durrance, 1989; 1995). It also does not correspond with the findings that three out of the five categories of behaviors (listening, searching, and follow up) were correlated with user satisfaction from the virtual reference encounter (Kwon, 2004). It is possible that the behaviors that affect satisfaction at the reference desk are less influential in the virtual environment.

\section{Implications}

Higher levels of adherence to each of the guidelines are expected to result in higher effectiveness. In order to achieve higher levels of effectiveness and to increase the appearance of certain behavioral guidelines, some of the less frequently observed behaviors can be automatically integrated into replies that are sent to users (e.g., thank you note, greetings, and a follow up comment). The appearance of other less frequent behaviors (e.g., makes evaluative remarks, explains search strategies, asks for more information, and rephrases the question) can be improved by increasing reference librarians' awareness through training and through the establishment of clear and detailed library policies.

Librarians should be aware of their tendencies to react differently to different user groups; administrators can help by providing diversity workshops and clear guidelines about service equality. Again, to improve these disturbing differences and to improve the level of service provided to some user groups (e.g., those represented by Ahmed), to be at least as high as other groups (e.g., those represented by Rosa) administrators should make efforts to increase reference librarians' awareness through training and the establishment of clear library policies. In addition, automatic solutions, such as those mentioned earlier, may prove to be useful. 


\section{Conclusion}

Virtual reference services are part of the core services that libraries provide to their users today. As the provision of these services mature, the availability of standards is lagging behind. Yet, professional associations have designed standards that could be utilized more frequently for the development, training, and evaluation of virtual reference services and providers. This study utilizes the standards for evaluation of service quality and evaluates the level of adherence to the guidelines by virtual of reference librarians. The implications of this study for future research and practice lie not only in its provision of a systematic way to analyze transactions in light of the ideal professional standards, but also by providing an empirical benchmark for evaluation of virtual reference services.

Future studies may look into real information needs that are presented by affiliated users, thus utilizing these guidelines to evaluate real transactions. It is possible that real information needs would result in a higher level of performance; it is likewise possible that the level of service provided to affiliated users may differ significantly from that provided to the unaffiliated users in this study. In addition, examination of the level of adherence to the guidelines in real time virtual reference transactions should be conducted; this study is limited in that includes only reference transactions conducted by e-mail, an asynchronous channel, and may not be indicative of other virtual reference services via synchronous channels. Future studies should explore the relationship between a variety of predictors and user satisfaction in the virtual environment. More research into what affects satisfaction in the virtual reference environment and how to improve the guidelines accordingly is needed. Finally, further investigations into how and why librarians' behavior varies when addressing different questions and different users is needed.

Richardson (2002, p. 41) claimed that "reference is better than we [practitioners, administrators, and researchers] thought." This study challenges that argument by focusing on virtual reference librarians' behaviors in light of the ideal standards for high quality virtual reference services. It evaluates reference transactions in a systematic way, utilizes and compares two set of guidelines, and provide an empirical benchmark for future studies. The study examines both behaviors (as described in both guidelines in detail) and outcomes (accuracy, completeness, and satisfaction) and manipulates institutions, requests types, and user names. Looking at the findings of this study one should ask: are reference librarians do better than we thought?

\section{References}

Alford, B. L., \& Sherrell, D. L. (1996). The role of affect in consumer satisfaction judgments of credence-based services. Journal of Business Research, 37, 71-84.

Arnold, J., \& Kaske, N. (2005). Evaluating the quality of a chat service. Portal: Libraries and the Academy, 5(2), 177-193.

Bitner, M. J., Booms, B. H., \& Tetreault, S. (1990). The service encounter: Diagnosing favorable and unfavorable incidents. Journal of Marketing, 54, 71-84.

Bobrowsky, T., Beck, L., \& Grant, M. (2005). The chat reference interview: Practicalities and advice. Reference Librarian, 43(89/90), 179-191.

Bopp, R., \& Smith, L. (2001). Reference and Information Services: An Introduction (3rd ed.). Englewood CO: Libraries Unlimited.

Bushallow-Wilbur, L., DeVinney, G., \& Whitcomb, F. (1996). Electronic mail reference service: A study. Reference Quarterly, 35(3), 359-371. Retrieved March 9, 2007 from 
http://www.carnegiefoundation.org/classifications/

The Carnegie Foundation for the Advancement of Teaching. (2000). The Carnegie Classification of Institutions of Higher Education.

Carter, D. S., \& Janes, J. (2003). Unobtrusive data analysis of digital reference questions and service at the Internet Public Library: An exploratory study. Library Trends, 49(2), 251-265.

Coffman, S. (2003). Going live: Starting and running a virtual reference service. Chicago, IL: American Library Association.

Coffman, S., \& Arret, L. (2004). To chat or not to chat: Taking yet another look at virtual reference. The Searcher, 12(8), 49-56.

Croft, R., \& Eichenlaud, N. (2006). E-mail reference in a distributed learning environment: Best practices, user satisfaction, and the reference services continuum. Journal of Library Administration, 45(1/2), 117-147.

Cummings, J., Cummings, L., \& Frederiksen, L. (2007). User preferences in reference services: Virtual reference and academic libraries. Portal: Libraries and the Academy, 7(1), 81-96.

Churchill, G. A., \& Surprenant, C. (1983). An investigation into the determinants of consumer satisfaction. Journal of Marketing Research, 19, 491-504.

Dewdney, P., \& Ross, C. S. (1994). Flying a light aircraft: Reference service evaluation from a user's viewpoint. Reference Quarterly, 34(2), 217-230.

Durrance, J. (1989). Reference success: Does the 55 percent rule tell the whole story? Library Journal, 114, 31-36.

Durrance, J. (1995). Factors that influence reference success: What makes questionnaires willing to return? The Reference Librarian, 49/50, 243-265.

Emery, J. (2005). Is our best good enough: Educating end-users about licensing terms. Journal of Library Administration, 42(3/4), 27-39.

Fagan, J. C., \& Desai, C. M. (2003). Communication strategies for instant messaging and chat reference services. Reference Librarian, 38(79/80), 121-156.

Fernandez, J. (2004). Facing live reference. Online, 28(3), 37-40

Gatten, J. N., \& Radcliff, C. J. (2001). Assessing reference behaviors with unobtrusive testing. In D.P. Wallace \& C. Van Fleet, (Eds), Library evaluation: A casebook and can-do guide (pp.105-15). Englewood, CO; Libraries Unlimited.

Gers, R., \& Seward, L.J. (1985). Improving reference service: Results of a state-wide survey. Library Journal, 110(18), 32-35.

Gilbert, L. M., Liu, M., Matoush, T., \& Whitlatch, J. B. (2006). Digital reference and online instructional services in an integrated public/university library. The Reference Librarian, 46(95-96), 149-172.

Gross, M., \& Saxton, M. L. (2002). Integrating the imposed query into the evaluation of reference service: A dichotomous analysis of user ratings. Library \& Information Science Research, 24, 251-263.

Hernon, P., \& Calvert, P. (2005). E-service quality in libraries: Exploring its features and dimensions. Library \& Information Science Research, 27, 377-404.

Hernon, P., \& McClure, C. R. (1986). Unobtrusive reference testing: The 55 percent rule. Library Journal, 111(7), 37-41.

International Federation of Library Associations (2005). IFLA digital reference guidelines. Retrieved January 5, 2006 from 
http://www.ifla.org/VII/s36/pubs/drg03.htm

Janes, J. (2002). Digital reference: Reference librarians' experiences and attitudes. Journal of the American Society for Information Science and Technology, 53(7), 549-566.

Kaske, N., \& Arnold, J. (2002). An unobtrusive evaluation of online real time library reference services. Retrieved February 20, 2005 from http://www.lib.umd.edu/groups/digref/kaskearnoldunobtrusive.html

Katz, W. A. (2002). Introduction to Reference Work. Vol.II: Reference Services and Reference Processes (8th ed.). New York: McGraw-Hill.

King, V., Nichols, J., \& Padilla, G. (2006). Moving back to campus: Creating a local virtual reference service. Internet Reference Services Quarterly, 11(3), 1-17.

Kwon, N. (2004). Assessing the virtual reference success using the revised RUSA guidelines for behavioral performance of reference and information service providers,

Proceedings of the 6th Virtual Reference Desk Annual Conference. Cincinnati, OH, November 8, 2004. Retrieved May 15, 2006 from http://www.vrd2004.org/proceedings/kwon.htm

Kwon, N. (2006). User satisfaction with referrals at a collaborative virtual reference service. Information Research, 11(2). Retrieved April, 19, 2005 from http://informationr.net/ir/11-2/paper246.html

Kwon, N. (2007). Public library patrons' use of collaborative chat reference service: The effectiveness of question answering by question type. Library \& Information Science Research, 29(1), 70-91

McClure, C., Lankes, R., D., Gross, M., \& Choltco-Devlin, B. (2002). Statistics, measures and quality standards for assessing digital library services: Guidelines and Procedures. ERIC Clearinghouse. Retrieved December 22, 2005 from http://quartz.syr.edu/rdlankes/tiki-download_file.php?fileId $=7$

Pomerantz, J., Lou, L., \& McClure, C. R. (2006). Peer review of chat reference transcripts: Approaches and strategies. Library \& Information Science Research, 28 (1), 24-48.

Pomerantz, J., Nicholson, S., Belanger, Y., \& Lankes, D. (2004). The current state of digital reference: Validation of a general digital reference model through a survey of digital reference services. Information Processing \& Management, 40, 347-363.

Radford, M. L. (2006). Encountering virtual users: A qualitative investigation of interpersonal communication in chat reference. Journal of the American Association for Information Science and Technology, 57(8), 1046-1059.

Reference and User Services Association (2004a). Guidelines for behavioral performance of reference and information service providers. Retrieved January 5 , 2006 from

http://www.ala.org/ala/rusa/rusaprotools/referenceguide/guidelinesbehavioral.htm

Reference and User Services Association (2004b). Guidelines for implementing and maintaining virtual reference services. Retrieved September 20, 2005 from http://www.ala.org/ala/rusa/rusaprotools/referenceguide/virtrefguidelines.htm

Richardson, J. V. (2002). Reference is better than we thought. Library Journal, 127(15), 41-42.

Ronan, J., Reakes, P., \& Cornwell, G. (2003). Evaluating online real-time reference in an academic library: Obstacles and recommendations. The Reference Librarian, 79/80, 
225-240.

Saxton, M. L., \& Richardson, J. V. (2002). Understanding reference transactions: Transforming an art into a science. New York: Academic Press.

Shachaf, P., \& Horowitz, S. (2006). Are virtual reference services color blind? Library \& Information Science Research, 28(4), 501-520.

Sloan, B. (1998). Electronic reference services: Some suggested guidelines. Reference and Users Services Quarterly, 38(1), 77-81.

Stacy- Bates, K. (2003). E-mail reference responses from academic ARL libraries: An unobtrusive study. Reference and User Services Quarterly, 43(1), 59-70.

Tunon, J., Barsun, R., \& Ramiraz, L. L. (2004). Pests, welcomed guests, or tolerated outsiders: Attitudes of academic librarians toward distance students from unaffiliated institutions. Journal of Library Administration, 41(3/4), 485-505.

Ueltschy, L. C., Laroche, M., Tamilia, T. D., \& Yannopoulosd, P. (2004). Cross-cultural invariance of measures of satisfaction and service quality. Journal of Business Research, 57(8), 901-912.

Walter, V. A., \& Mediavilla, C. (2005). Teens are from Neptune, librarians are from Pluto: An analysis of online reference transactions. Library Trends, 54(2), 209-227.

Ward, D. (2003). Measuring the completeness of reference transactions in online chats; Results of an unobtrusive study. Reference and User Services Quarterly, 44(1), 4658.

Ward, D. (2005). Why users choose chat?: A survey of behavior and motivations. Internet Reference Services Quarterly, 10(1), 29-46.

White, M. D. (2001). Digital reference services: Framework for analysis and evaluation. Library \& Information Science Research, 23, 211-231.

Whitlatch, J. B. (1989). Unobtrusive studies and the quality of academic reference services. College \& Research Libraries, 50(2), 181-194.

Whitlatch, J.B. (1990). Reference service effectiveness. Reference Quarterly, 30(2), 205220

Whitlatch, J. B. (2001). Evaluating reference services in the electronic age. Library Trends, 50(2), 207-217.

Zhuo F., Love, M., Norwood, S., \& Massia, K. (2006). Applying RUSA guidelines in the analysis of chat reference transcripts. College \& Undergraduate Libraries, 13(1), 7588

\section{Legend of Tables and Figures:}

Table 1. IFLA guidelines coding scheme (2005)

Table 2. RUSA guidelines coding scheme (2004a)

Table 3. Attributes table

Table 4. Frequencies and percentage IFLA guidelines codes

Table 5. Frequencies and percentage of RUSA guidelines codes

Table 6. Frequencies of IFLA guidelines codes by user name

Table 7. Frequencies of RUSA guidelines codes by user name

Table 8. Frequencies of IFLA and RUSA guidelines codes by institution and institutions' ranking 
Table 9. Frequencies of IFLA guidelines codes by request type

Table 10. Frequencies of RUSA codes by request type

Table 11. Adherence to time policies on weekdays and over the weekend

Table 12. Satisfaction, accuracy, and total frequency of adherence to IFLA and RUSA guidelines by institution

Table 13. Correlations matrix

Figure 1. Frequencies of IFLA and RUSA guidelines codes by user name

Figure 2. Frequencies of IFLA and RUSA guidelines by institution

Figure 3. Frequencies of IFLA and RUSA guidelines codes by request type 
Table 1. IFLA guidelines coding scheme (2005)

\begin{tabular}{|c|c|c|c|}
\hline IFLA guidelines & Code & Definition & Code Example \\
\hline \multirow[t]{2}{*}{$\begin{array}{l}\text { Show professional courtesy } \\
\text { and respect when answering } \\
\text { questions }\end{array}$} & $\begin{array}{l}\text { Thanks the user } \\
\text { for using the } \\
\text { service }\end{array}$ & Thank you for using & $\begin{array}{l}\text { Thank you for } \\
\text { contacting ask a } \\
\text { librarian }\end{array}$ \\
\hline & $\begin{array}{l}\text { Uses honorific } \\
\text { to address the } \\
\text { user }\end{array}$ & $\begin{array}{l}\text { Greetings/name/with } \\
\text { honorific }\end{array}$ & $\begin{array}{l}\text { Ms. Anderson, Mr. } \\
\text { Cohen }\end{array}$ \\
\hline \multirow[t]{2}{*}{$\begin{array}{l}\text { Acknowledge receipt of } \\
\text { patron question. Provide } \\
\text { patrons with responses as } \\
\text { quickly as possible. Letters } \\
\text { and other forms of } \\
\text { communication should be } \\
\text { answered promptly and } \\
\text { courteously }\end{array}$} & $\begin{array}{l}\text { Sends } \\
\text { automatic } \\
\text { response to } \\
\text { acknowledge } \\
\text { the receipt of } \\
\text { patron question } \\
\text { (attribute) }\end{array}$ & $\begin{array}{l}\text { *attribute } \\
\text { Automatic response sent }\end{array}$ & $\begin{array}{l}\text { An auto-generated } \\
\text { reply was sent to the } \\
\text { user, saying that their } \\
\text { question had been } \\
\text { received }\end{array}$ \\
\hline & $\begin{array}{l}\text { Sends prompt } \\
\text { reply - reply } \\
\text { sent on the } \\
\text { same day } \\
\text { (attribute) }\end{array}$ & $\begin{array}{l}* \text { attribute } \\
\text { Response time }\end{array}$ & $\begin{array}{l}\text { Response time was } \\
\text { less than } 24 \text { hours }\end{array}$ \\
\hline \multirow[t]{2}{*}{$\begin{array}{l}\text { Create and adhere to stated } \\
\text { response turnaround policy. }\end{array}$} & $\begin{array}{l}\text { Provides } \\
\text { response time } \\
\text { policy on } \\
\text { library website }\end{array}$ & Provides response time & $\begin{array}{l}\text { Expected response } \\
\text { time was found on the } \\
\text { library or ask a } \\
\text { librarian website }\end{array}$ \\
\hline & $\begin{array}{l}\text { Adheres to } \\
\text { response time } \\
\text { policy } \\
\text { (attribute) }\end{array}$ & $\begin{array}{l}\text { Provides response time/ } \\
\text { follows time policy }\end{array}$ & $\begin{array}{l}\text { A response was } \\
\text { received within the } \\
\text { stated } 48 \text { hour limit }\end{array}$ \\
\hline $\begin{array}{l}\text { Comply with contractual } \\
\text { licensing agreements, for both } \\
\text { electronic and print materials, } \\
\text { as well as specific restrictions } \\
\text { of use, and any copyright } \\
\text { laws governing the materials } \\
\text { in question. }\end{array}$ & $\begin{array}{l}\text { Does not } \\
\text { provide full } \\
\text { text articles } \\
\text { retrieved from } \\
\text { licensed } \\
\text { materials to } \\
\text { unaffiliated } \\
\text { users. }\end{array}$ & $\begin{array}{l}\text { Opposite of: } \\
\text { answer/article sent and } \\
\text { answer/ book chapter } \\
\text { sent }\end{array}$ & $\begin{array}{l}\text { I'm sorry, but due to } \\
\text { licensing restrictions } \\
\text { we cannot email you a } \\
\text { copy of this article } \\
\text { (applies only to article } \\
\text { and book chapter } \\
\text { questions) }\end{array}$ \\
\hline $\begin{array}{l}\text { Practice good search } \\
\text { strategies. See RUSA } \\
\text { document: Guidelines for }\end{array}$ & $\begin{array}{l}\text { See Table } 2- \\
\text { searching }- \text { for } \\
\text { detailed coding }\end{array}$ & & $\begin{array}{l}\text { This was indirectly } \\
\text { included; see the } \\
\text { RUSA table for }\end{array}$ \\
\hline
\end{tabular}




\begin{tabular}{|c|c|c|c|}
\hline $\begin{array}{l}\text { Behavioral Performance of } \\
\text { Reference and Information } \\
\text { Services Professionals. } \\
\text { Section } 4.0 \text { Searching. }\end{array}$ & & & $\begin{array}{l}\text { specific searching } \\
\text { codes }\end{array}$ \\
\hline $\begin{array}{l}\text { Respond to } 100 \% \text { of } \\
\text { questions that are assigned, if } \\
\text { only to say, "I'm sorry I don't } \\
\text { know, but you can try..." }\end{array}$ & $\begin{array}{l}\text { Percent of } \\
\text { responses to } \\
\text { queries, NOT } \\
\text { includes } \\
\text { automatic } \\
\text { responses } \\
\text { (attribute) }\end{array}$ & $\begin{array}{l}* \text { attribute } \\
\text { Response received }\end{array}$ & $\begin{array}{l}\text { Whether any email } \\
\text { was received from a } \\
\text { librarian }\end{array}$ \\
\hline $\begin{array}{l}\text { Digital reference service } \\
\text { should be informative; } \\
\text { Promote information literacy } \\
\text { by providing patrons with } \\
\text { information on how you } \\
\text { found an answer to their } \\
\text { question. }\end{array}$ & $\begin{array}{l}\text { Search strategy } \\
\text { explained }\end{array}$ & Search strategies explained & $\begin{array}{l}\text { To find this yourself, } \\
\text { go to the Project Muse } \\
\text { database and enter the } \\
\text { search... }\end{array}$ \\
\hline $\begin{array}{l}\text { Maintain objectivity and do } \\
\text { not interject value judgments } \\
\text { about subject matter or the } \\
\text { nature of the question into the } \\
\text { transaction. }\end{array}$ & $\begin{array}{l}\text { Objective } \\
\text { behavior }\end{array}$ & Objective behavior & $\begin{array}{l}\text { The librarian is } \\
\text { objective about the } \\
\text { question and the user }\end{array}$ \\
\hline \multirow{4}{*}{$\begin{array}{l}\text { Use a neutral questioning } \\
\text { interview technique to } \\
\text { determine "the real question," } \\
\text { and once this is determined, } \\
\text { provide users with accurate } \\
\text { answers, appropriate in } \\
\text { length, level, and } \\
\text { completeness to the need. }\end{array}$} & $\begin{array}{l}\text { Neutral } \\
\text { questioning } \\
\text { technique }\end{array}$ & Neutral questioning & $\begin{array}{l}\text { Could you give me a } \\
\text { few more details } \\
\text { about the kind of } \\
\text { information you } \\
\text { want? }\end{array}$ \\
\hline & $\begin{array}{l}\text { Accurate } \\
\text { answer }\end{array}$ & Answer/accurate answer & $\begin{array}{l}\text { The question was } \\
\text { answered accurately } \\
\text { (applies only to } \\
\text { dissertation and } \\
\text { population) }\end{array}$ \\
\hline & $\begin{array}{l}\text { Appropriate } \\
\text { length and } \\
\text { level }\end{array}$ & Appropriate length and level & $\begin{array}{l}\text { The length and level } \\
\text { of response were } \\
\text { appropriate to the } \\
\text { question asked and the } \\
\text { user }\end{array}$ \\
\hline & Completeness & $\begin{array}{l}\text { Coded by question: } \\
\text { Answer/subject/complete } \\
\text { Answer/population question } \\
\text { answered } \\
\text { Answer/dissertation/complete }\end{array}$ & $\begin{array}{l}\text { All parts of a } \\
\text { multipart } \\
\text { question were } \\
\text { answered (i.e., both an } \\
\text { answer and a source), }\end{array}$ \\
\hline
\end{tabular}




\begin{tabular}{|c|c|c|c|}
\hline & & $\begin{array}{l}\text { Answer/mascot/complete } \\
\text { Answer/book chapter } \\
\text { sent } \\
\text { Answer/article sent }\end{array}$ & $\begin{array}{l}\text { and the request that } \\
\text { was made was } \\
\text { fulfilled (i.e., sending } \\
\text { the article, not saying } \\
\text { how to find it) }\end{array}$ \\
\hline $\begin{array}{l}\text { For questions requiring more } \\
\text { in-depth answers, assistance } \\
\text { may be provided if } \\
\text { appropriate. Search time } \\
\text { should be limited to the } \\
\text { amount of time that } \\
\text { supervisor recommends. }\end{array}$ & $\begin{array}{l}\text { Recommends } \\
\text { coming to the } \\
\text { library for in } \\
\text { depth help. }\end{array}$ & $\begin{array}{l}\text { Referral was made/ } \\
\text { library for further help }\end{array}$ & $\begin{array}{l}\text { User was advised to } \\
\text { come to the library for } \\
\text { help with this type of } \\
\text { question }\end{array}$ \\
\hline $\begin{array}{l}\text { A well-structured written } \\
\text { response has a heading, body } \\
\text { and closure. }\end{array}$ & $\begin{array}{l}\text { Includes } \\
\text { headings, } \\
\text { body, and } \\
\text { closure. }\end{array}$ & $\begin{array}{l}\text { Includes heading, body, } \\
\text { closure }\end{array}$ & $\begin{array}{l}\text { The response included } \\
\text { all three structural } \\
\text { elements }\end{array}$ \\
\hline \multirow{3}{*}{$\begin{array}{l}\text { Heading: Greet patron, } \\
\text { include a generic notice of } \\
\text { thanks for using the service, } \\
\text { refer directly to subject of } \\
\text { patron's inquiry: Example: } \\
\text { "Information } \\
\text { on_ may be } \\
\text { found_ To find out } \\
\text { more about_, we } \\
\text { would recommend___, w_ }\end{array}$} & Greet patron & Greetings/hello & Hello, hi, dear \\
\hline & $\begin{array}{l}\text { Thank the } \\
\text { patron for } \\
\text { using the } \\
\text { service }\end{array}$ & Thank you for using & $\begin{array}{l}\text { Thank you for } \\
\text { contacting ask a } \\
\text { librarian }\end{array}$ \\
\hline & $\begin{array}{l}\text { Refers directly } \\
\text { to the subject } \\
\text { of patron's } \\
\text { inquiry; a } \\
\text { specific } \\
\text { reference to the } \\
\text { question asked, } \\
\text { near the } \\
\text { beginning of } \\
\text { the article }\end{array}$ & Refers directly to subject & $\begin{array}{l}\text { In response to your } \\
\text { question about the } \\
\text { population of town } X \\
\text { in } 1993 \ldots\end{array}$ \\
\hline \multirow{2}{*}{$\begin{array}{l}\text { Signature: A signature } \\
\text { should be a part of every } \\
\text { closure. The librarian } \\
\text { signature may contain } \\
\text { librarian name or initials, title, } \\
\text { institution and any contact } \\
\text { information, as is prescribed } \\
\text { by supervisor. } \\
\text { Examples: "We hope the } \\
\text { information we've } \\
\text { provided will assist you with } \\
\text { your research"; "I hope you }\end{array}$} & $\begin{array}{l}\text { Includes } \\
\text { signature }\end{array}$ & $\begin{array}{l}\text { Includes the codes: } \\
\text { Closure/ name of librarian } \\
\text { Closure/ initials of librarian } \\
\text { Closure/ department } \\
\text { Closure/ contact information }\end{array}$ & $\begin{array}{l}\text { Jane Doe } \\
\text { Reference Department } \\
\text { jdoe@university.edu }\end{array}$ \\
\hline & $\begin{array}{l}\text { Includes } \\
\text { concluding } \\
\text { remarks }\end{array}$ & Closure/ concluding remarks & $\begin{array}{l}\text { I hope this } \\
\text { information is helpful } \\
\text { to you }\end{array}$ \\
\hline
\end{tabular}




\begin{tabular}{|c|c|c|c|}
\hline $\begin{array}{l}\text { find this information helpful"; } \\
\text { "We hope this answers your } \\
\text { question. If you have further } \\
\text { questions, please contact us } \\
\text { again and we will be glad to } \\
\text { provide additional } \\
\text { assistance..." }\end{array}$ & & & \\
\hline $\begin{array}{l}\text { Avoid using jargon, } \\
\text { acronyms, or Internet } \\
\text { abbreviations (such as: BTW, } \\
\text { IMHO). }\end{array}$ & $\begin{array}{l}\text { Includes } \\
\text { jargon, Internet } \\
\text { abbreviations, } \\
\text { or acronyms }\end{array}$ & $\begin{array}{l}\text { Opposite: } \\
\text { Jargon }\end{array}$ & UMI, OCLC \\
\hline $\begin{array}{l}\text { Write all responses clearly } \\
\text { and relate them to the level of } \\
\text { the inquiry (as much as } \\
\text { possible). }\end{array}$ & $\begin{array}{l}\text { Clarity of } \\
\text { response }\end{array}$ & Clarity of response & $\begin{array}{l}\text { The response was } \\
\text { clear and easy to } \\
\text { understand }\end{array}$ \\
\hline $\begin{array}{l}\text { Offer accurate responses-- } \\
\text { check facts and know } \\
\text { (evaluate) sources. }\end{array}$ & $\begin{array}{l}\text { Response is } \\
\text { accurate }\end{array}$ & Answer/ accurate response & $\begin{array}{l}\text { The question was } \\
\text { answered accurately } \\
\text { (applies only to } \\
\text { dissertation and } \\
\text { population) }\end{array}$ \\
\hline $\begin{array}{l}\text { Check spelling in written } \\
\text { responses, and validate } \\
\text { URLS. }\end{array}$ & $\begin{array}{l}\text { No } \\
\text { misspellings or } \\
\text { broken links. }\end{array}$ & $\begin{array}{l}\text { Opposite Include the codes: } \\
\text { Misspellings } \\
\text { Broken links }\end{array}$ & $\begin{array}{l}\text { Words are misspelled } \\
\text { or links do not work }\end{array}$ \\
\hline $\begin{array}{l}\text { Select and cite only from } \\
\text { authoritative resources. }\end{array}$ & $\begin{array}{l}\text { Use } \\
\text { authoritative } \\
\text { sources }\end{array}$ & Authoritative sources & $\begin{array}{l}\text { Authoritative sources } \\
\text { used to answer } \\
\text { questions (i.e., } \\
\text { dissertation abstracts } \\
\text { or catalog; university } \\
\text { website or newspaper; } \\
\text { census; etc.) }\end{array}$ \\
\hline $\begin{array}{l}\text { The librarian should add } \\
\text { value to information either } \\
\text { through analysis, description, } \\
\text { keywords, } \\
\text { pathways, or rewording. }\end{array}$ & Adds value & Evaluative remarks made & $\begin{array}{l}\text { The first resource is } \\
\text { probably the best } \\
\text { because it includes } \\
\text { primary studies }\end{array}$ \\
\hline $\begin{array}{l}\text { The librarian should do his or } \\
\text { her best to locate and } \\
\text { recommend at least one } \\
\text { resource for every question. }\end{array}$ & $\begin{array}{l}\text { Provides at } \\
\text { least one } \\
\text { resource }\end{array}$ & Gives at least one resource & $\begin{array}{l}\text { At least one resource } \\
\text { was given when a } \\
\text { source was asked for } \\
\text { (applies only to the } \\
\text { topical question) }\end{array}$ \\
\hline
\end{tabular}


Table 2. RUSA guidelines coding scheme (2004a)

\begin{tabular}{|c|c|c|c|}
\hline RUSA Guidelines & Code Definition & Code & Example \\
\hline \multirow{2}{*}{$\begin{array}{l}\text { 1.1 Establishes a "reference } \\
\text { presence" wherever patrons look } \\
\text { for it. This includes having } \\
\text { Reference Services in a highly } \\
\text { visible location and using proper } \\
\text { signage (both in the library and } \\
\text { on the library's Web site) to } \\
\text { indicate the location, hours, and } \\
\text { availability of in-person and } \\
\text { remote help or assistance. } \\
1.8 \text { Should provide prominent, } \\
\text { jargon-free links to all forms of } \\
\text { reference services from the home } \\
\text { page of the library's Web site, } \\
\text { and throughout the site wherever } \\
\text { research assistance may be } \\
\text { sought out. The Web should be } \\
\text { used to make reference services } \\
\text { easy to find and convenient. }\end{array}$} & $\begin{array}{l}\text { Number of clicks } \\
\text { from library homepage } \\
\text { to get to remote } \\
\text { service. }\end{array}$ & $\begin{array}{l}\text { *attribute } \\
\text { Clicks to remote } \\
\text { service }\end{array}$ & $\begin{array}{l}2 \text { pages from library } \\
\text { homepage to } \\
\text { webform or email } \\
\text { address }\end{array}$ \\
\hline & $\begin{array}{l}\text { Policies are made } \\
\text { public. }\end{array}$ & Policies made public & $\begin{array}{l}\text { Information about } \\
\text { who can use this } \\
\text { service and for what } \\
\text { given on website }\end{array}$ \\
\hline $\begin{array}{l}\text { 1.2 Is poised and ready to engage } \\
\text { approaching patrons. The } \\
\text { librarian is aware of the need to } \\
\text { stop all other activities when } \\
\text { patrons approach and focus } \\
\text { attention on the patrons' needs. } \\
\text { 1.3 Acknowledges others waiting } \\
\text { for service. }\end{array}$ & $\begin{array}{l}\text { Acknowledgement } \\
\text { of message received } \\
\text { either by an automatic } \\
\text { response or by an } \\
\text { immediate reply to the } \\
\text { user request. }\end{array}$ & $\begin{array}{l}\text { *attribute } \\
\text { Automatic response }\end{array}$ & $\begin{array}{l}\text { An autogenerated } \\
\text { reply was sent to the } \\
\text { user, saying that } \\
\text { their question had } \\
\text { been } \\
\text { received }\end{array}$ \\
\hline $\begin{array}{l}\text { 1.5 Acknowledges patrons } \\
\text { through the use of a friendly } \\
\text { greeting to initiate conversation, } \\
\text { and by standing up, moving } \\
\text { forward, or moving closer to } \\
\text { them. Introduction: In order to } \\
\text { have a successful reference } \\
\text { transaction, patrons must be able } \\
\text { to identify that a reference } \\
\text { librarian is available to provide } \\
\text { assistance and also must feel } \\
\text { comfortable in going to that } \\
\text { person for } \\
\text { help...Approachability } \\
\text { behaviors, such as the initial } \\
\text { verbal and nonverbal responses } \\
\text { of the librarian, will set the tone }\end{array}$ & $\begin{array}{l}\text { Greetings (hello, use } \\
\text { honorific). }\end{array}$ & $\begin{array}{l}\text { Includes codes: } \\
\text { Greetings/ hello }\end{array}$ & Hello, hi, dear \\
\hline
\end{tabular}




\begin{tabular}{|c|c|c|c|}
\hline $\begin{array}{l}\text { for the entire communication } \\
\text { process, and will influence the } \\
\text { depth and level of interaction } \\
\text { between the staff and the } \\
\text { patrons. At this stage in the } \\
\text { process, the behaviors exhibited } \\
\text { by the staff member should serve } \\
\text { to welcome the patrons and to } \\
\text { place them at ease. The } \\
\text { librarian's role in the } \\
\text { communications process is to } \\
\text { make the patrons feel } \\
\text { comfortable in a situation that } \\
\text { may be perceived as } \\
\text { intimidating, risky, confusing, } \\
\text { and overwhelming. }\end{array}$ & & & \\
\hline $\begin{array}{l}2.2 \text { Focuses attention on the } \\
\text { patrons. }\end{array}$ & $\begin{array}{l}\text { Greet the patron by } \\
\text { name (first name or } \\
\text { full name) }\end{array}$ & $\begin{array}{l}\text { Includes codes: } \\
\text { Greetings/name/first } \\
\text { Greetings/name/full } \\
\text { Greetings/name/with } \\
\text { honorific }\end{array}$ & $\begin{array}{l}\text { Mary } \\
\text { Mary Anderson } \\
\text { Ms. Anderson }\end{array}$ \\
\hline $\begin{array}{l}2.7 \text { Acknowledges user email } \\
\text { questions in a timely manner. }\end{array}$ & $\begin{array}{l}\text { Automatic } \\
\text { acknowledgement or } \\
\text { reply to request within } \\
\text { stated response time } \\
\text { policies. }\end{array}$ & $\begin{array}{l}\text { *attribute } \\
\text { Automatic response }\end{array}$ & $\begin{array}{l}\text { An autogenerated } \\
\text { reply was sent to the } \\
\text { user, saying that } \\
\text { their question had } \\
\text { been received }\end{array}$ \\
\hline \multirow{3}{*}{$\begin{array}{l}\text { 2.8 States question answering } \\
\text { procedures and policies clearly } \\
\text { in an accessible place on the } \\
\text { Web. This should indicate } \\
\text { question scope, types of answers } \\
\text { provided, and expected } \\
\text { turnaround time. }\end{array}$} & $\begin{array}{l}\text { Policies available on } \\
\text { website. }\end{array}$ & Policies made public & $\begin{array}{l}\text { Information about } \\
\text { who can use this } \\
\text { service and for what } \\
\text { given on website }\end{array}$ \\
\hline & $\begin{array}{l}\text { Policies include } \\
\text { question scope. }\end{array}$ & $\begin{array}{l}\text { Policies made } \\
\text { public/ } \\
\text { include question } \\
\text { scope }\end{array}$ & $\begin{array}{l}\text { This service is } \\
\text { designed to answer } \\
\text { brief, factual } \\
\text { questions }\end{array}$ \\
\hline & $\begin{array}{l}\text { Policies include type } \\
\text { of answer provided. }\end{array}$ & $\begin{array}{l}\text { Policies made } \\
\text { public/include type } \\
\text { of answer provided/ } \\
\text { instructions on scope } \\
\text { Policies made } \\
\text { public/include type } \\
\text { of answer provided/ } \\
\text { only some resources } \\
\text { Policies made } \\
\text { public/include type } \\
\text { of answer provided/ }\end{array}$ & $\begin{array}{l}\text { We will answer } \\
\text { questions only from } \\
\text { affiliated users or } \\
\text { about resources } \\
\text { specific to the } \\
\text { library and the } \\
\text { university }\end{array}$ \\
\hline
\end{tabular}




\begin{tabular}{|c|c|c|c|}
\hline & & via certain method & \\
\hline & $\begin{array}{l}\text { Policies include } \\
\text { expected turnaround } \\
\text { time }\end{array}$ & $\begin{array}{l}\text { Policies made } \\
\text { public/include } \\
\text { turnaround time }\end{array}$ & $\begin{array}{l}\text { You should receive } \\
\text { an answer within } 2 \\
\text { business days }\end{array}$ \\
\hline $\begin{array}{l}3.1 \text { Communicates in a receptive, } \\
\text { cordial, and encouraging manner. }\end{array}$ & $\begin{array}{l}\text { Cordial - use of } \\
\text { honorific, please, } \\
\text { thank you. }\end{array}$ & $\begin{array}{l}\text { Includes codes: } \\
\text { Thank you for using } \\
\text { Greetings/name/hon } \\
\text { orific }\end{array}$ & $\begin{array}{l}\text { Thank you for } \\
\text { contacting ask a } \\
\text { librarian }\end{array}$ \\
\hline $\begin{array}{l}3.2 \text { Uses a tone of voice and/or } \\
\text { written language appropriate to } \\
\text { the nature of the transaction. }\end{array}$ & $\begin{array}{l}\text { Appropriate written } \\
\text { language }\end{array}$ & $\begin{array}{l}\text { Appropriate written } \\
\text { language }\end{array}$ & $\begin{array}{l}\text { Librarian uses } \\
\text { language } \\
\text { appropriate to the } \\
\text { question }\end{array}$ \\
\hline $\begin{array}{l}\text { 3.5 Rephrases the question or } \\
\text { request and asks for confirmation } \\
\text { to ensure that it is understood. }\end{array}$ & Rephrase the question. & $\begin{array}{l}\text { Rephrase the } \\
\text { question }\end{array}$ & $\begin{array}{l}\text { In response to your } \\
\text { question about the } \\
\text { population of town } \\
X \text { in } 1993 \ldots\end{array}$ \\
\hline $\begin{array}{l}\text { 3.6 Seeks to clarify confusing } \\
\text { terminology and avoids } \\
\text { excessive jargon. }\end{array}$ & $\begin{array}{l}\text { Avoids excessive } \\
\text { jargon (or heavy use } \\
\text { of acronyms). }\end{array}$ & $\begin{array}{l}\text { Opposite: } \\
\text { Jargon }\end{array}$ & UMI, LOL \\
\hline $\begin{array}{l}\text { 3.7 Uses open-ended questioning } \\
\text { techniques to encourage patrons } \\
\text { to expand on the request or } \\
\text { present additional information. } \\
\text { Some examples of such } \\
\text { questions include: Please tell me } \\
\text { more about your topic. } \\
\text { What additional information can } \\
\text { you give me? How much } \\
\text { information do you need? }\end{array}$ & Use open questions. & Open questions & $\begin{array}{l}\text { Could you give me a } \\
\text { few more details } \\
\text { about the kind of } \\
\text { information you } \\
\text { want? }\end{array}$ \\
\hline $\begin{array}{l}\text { 3.8 Uses closed and/or clarifying } \\
\text { questions to refine the search } \\
\text { query. Some examples of } \\
\text { clarifying questions are: What } \\
\text { have you already found? What } \\
\text { type of information do you need } \\
\text { (books, articles, etc.)? Do you } \\
\text { need current or historical } \\
\text { information? }\end{array}$ & Use closed questions. & Closed questions & $\begin{array}{l}\text { Could you be more } \\
\text { specific as to which } \\
\text { aspect you are } \\
\text { researching? } \\
\text { Are you interested } \\
\text { in the history of } \\
\text { the...? The United } \\
\text { States as a whole? } \\
\text { Other parts of the } \\
\text { world? } \\
\text { Contemporary } \\
\text { history? or ... }\end{array}$ \\
\hline 3.9 Maintains objectivity and & Maintains objectivity. & Objective & The librarian is \\
\hline
\end{tabular}




\begin{tabular}{|c|c|c|c|}
\hline $\begin{array}{l}\text { does not interject value } \\
\text { judgments about subject matter } \\
\text { or the nature of the question into } \\
\text { the transaction. }\end{array}$ & & & $\begin{array}{l}\text { objective about the } \\
\text { question and the } \\
\text { user }\end{array}$ \\
\hline $\begin{array}{l}\text { 3.10 Uses reference interviews or } \\
\text { Web forms to gather as much } \\
\text { information as possible without } \\
\text { compromising user privacy. }\end{array}$ & $\begin{array}{l}\text { Use of web forms to } \\
\text { gather information. }\end{array}$ & $\begin{array}{l}\text { *attribute } \\
\text { Uses web form }\end{array}$ & $\begin{array}{l}\text { A web form is used } \\
\text { to gather } \\
\text { information for the } \\
\text { question, as opposed } \\
\text { to an email address }\end{array}$ \\
\hline $\begin{array}{l}\text { Introduction: The search process } \\
\text { is the portion of the transaction } \\
\text { in which behavior and accuracy } \\
\text { intersect. Without an effective } \\
\text { search, not only is the desired } \\
\text { information unlikely to be found, } \\
\text { but patrons may become } \\
\text { discouraged as well. Yet many of } \\
\text { the aspects of searching that lead } \\
\text { to accurate results are still } \\
\text { dependent on the behavior of the } \\
\text { librarian. }\end{array}$ & Accuracy of response. & $\begin{array}{l}\text { Answer/ accurate } \\
\text { answer }\end{array}$ & $\begin{array}{l}\text { The question was } \\
\text { answered accurately } \\
\text { (applies only to } \\
\text { dissertation and } \\
\text { population) }\end{array}$ \\
\hline $\begin{array}{l}\text { 4.1 Finds out what patrons have } \\
\text { already tried, and encourages } \\
\text { patrons to contribute ideas. }\end{array}$ & $\begin{array}{l}\text { Ask patron what have } \\
\text { been already tried. }\end{array}$ & $\begin{array}{l}\text { Ask what already } \\
\text { tried }\end{array}$ & $\begin{array}{l}\text { Where have you } \\
\text { looked for this } \\
\text { information? }\end{array}$ \\
\hline $\begin{array}{l}\text { 4.3 Explains the search strategy } \\
\text { and sequence to the patrons, as } \\
\text { well as the sources to be used. }\end{array}$ & $\begin{array}{l}\text { Search strategy } \\
\text { explained. }\end{array}$ & $\begin{array}{l}\text { Search strategies } \\
\text { explained }\end{array}$ & $\begin{array}{l}\text { To find this } \\
\text { yourself, go to the } \\
\text { Project Muse } \\
\text { database and enter } \\
\text { the search... }\end{array}$ \\
\hline $\begin{array}{l}\text { 4.5 Explains how to use sources } \\
\text { when appropriate. }\end{array}$ & $\begin{array}{l}\text { Explain how to use } \\
\text { sources. }\end{array}$ & $\begin{array}{l}\text { Instructions provided } \\
\text { - how to use }\end{array}$ & $\begin{array}{l}\text { To find the library } \\
\text { catalog, go first to } \\
\text { the library } \\
\text { website... }\end{array}$ \\
\hline $\begin{array}{l}\text { 4.6 Works with the patrons to } \\
\text { narrow or broaden the topic } \\
\text { when too little or too much } \\
\text { information is } \\
\text { identified. }\end{array}$ & $\begin{array}{l}\text { Suggest to narrow or } \\
\text { broaden the topic. }\end{array}$ & $\begin{array}{l}\text { Suggests broader or } \\
\text { narrower topic }\end{array}$ & $\begin{array}{l}\text { This is a very broad } \\
\text { topic, so you might } \\
\text { think about looking } \\
\text { at the history } \\
\text { specifically in the } \\
\text { American West... } \\
\text { (applies only to the } \\
\text { topical question) }\end{array}$ \\
\hline $\begin{array}{l}\text { 4.7 Asks the patrons if additional } \\
\text { information is needed after an }\end{array}$ & $\begin{array}{l}\text { Ask the patron if } \\
\text { additional sources are }\end{array}$ & Follow up & $\begin{array}{l}\text { If you need any } \\
\text { further information, }\end{array}$ \\
\hline
\end{tabular}




\begin{tabular}{|c|c|c|c|}
\hline initial result is found. & needed. (follow up) & & $\begin{array}{l}\text { please feel free to } \\
\text { contact us again }\end{array}$ \\
\hline $\begin{array}{l}\text { 4.8 Recognizes when to refer } \\
\text { patrons to a more appropriate } \\
\text { guide, database, library, } \\
\text { librarian, } \\
\text { or other resource. }\end{array}$ & $\begin{array}{l}\text { Refer patron to more } \\
\text { appropriate source. }\end{array}$ & $\begin{array}{l}\text { Referral was made/ } \\
\text { more appropriate } \\
\text { source }\end{array}$ & $\begin{array}{l}\text { We do not provide } \\
\text { services for } \\
\text { unaffiliated users; } \\
\text { you may want to ask } \\
\text { at your local library }\end{array}$ \\
\hline $\begin{array}{l}4.9 \text { Offers pointers, detailed } \\
\text { search paths (including complete } \\
\text { URLs), and names of resources } \\
\text { used to find the answer, so that } \\
\text { patrons can learn to answer } \\
\text { similar questions on their own. }\end{array}$ & $\begin{array}{l}\text { Offer detailed search } \\
\text { paths, names of } \\
\text { sources and complete } \\
\text { urls. } \\
\text { ("detailed information } \\
\text { on sources") }\end{array}$ & $\begin{array}{l}\text { Detailed info on } \\
\text { sources }\end{array}$ & $\begin{array}{l}\text { Complete citations } \\
\text { and source } \\
\text { information, } \\
\text { including publisher } \\
\text { and date }\end{array}$ \\
\hline $\begin{array}{l}\text { 5.1 Asks patrons if their } \\
\text { questions have been completely } \\
\text { answered. }\end{array}$ & $\begin{array}{l}\text { "I hope this answers } \\
\text { your question." } \\
\text { (concluding remarks) }\end{array}$ & $\begin{array}{l}\text { Closure/ Concluding } \\
\text { remarks }\end{array}$ & $\begin{array}{l}\text { I hope this } \\
\text { information is } \\
\text { helpful to you }\end{array}$ \\
\hline $\begin{array}{l}5.2 \text { Encourages the patrons to } \\
\text { return if they have further } \\
\text { questions by making a statement } \\
\text { such as } \\
\text { "If you don't find what you are } \\
\text { looking for, please come back } \\
\text { and we'll try something else." }\end{array}$ & $\begin{array}{l}\text { "If you don't find } \\
\text { what you are looking } \\
\text { for, please come back } \\
\text { and we'll try } \\
\text { something else." } \\
\text { (follow up) }\end{array}$ & Follow up & $\begin{array}{l}\text { If you need any } \\
\text { further information, } \\
\text { please feel free to } \\
\text { contact us again }\end{array}$ \\
\hline $\begin{array}{l}\text { 5.4 Consults other librarians or } \\
\text { experts in the field when } \\
\text { additional subject expertise is } \\
\text { needed. }\end{array}$ & $\begin{array}{l}\text { Referral to an expert } \\
\text { in the library }\end{array}$ & $\begin{array}{l}\text { Referral was made/ } \\
\text { to expert in library }\end{array}$ & $\begin{array}{l}\text { I am referring this } \\
\text { question to our } \\
\text { government } \\
\text { documents librarian. } \\
\text { You should be } \\
\text { hearing from her } \\
\text { shortly. }\end{array}$ \\
\hline $\begin{array}{l}5.5 \text { Makes patrons aware of other } \\
\text { appropriate reference services } \\
\text { (email, etc.). }\end{array}$ & $\begin{array}{l}\text { Make patron aware of } \\
\text { in person or phone } \\
\text { services }\end{array}$ & $\begin{array}{l}\text { Referral was made/ } \\
\text { other library services } \\
\text { - phone, in person }\end{array}$ & $\begin{array}{l}\text { We will be happy to } \\
\text { assist you if you } \\
\text { come to the } \\
\text { reference desk at the } \\
\text { library, or call us. }\end{array}$ \\
\hline $\begin{array}{l}\text { 5.6 Makes arrangements, when } \\
\text { appropriate, with the patrons to } \\
\text { research a question even after the } \\
\text { reference transaction has been } \\
\text { completed. }\end{array}$ & $\begin{array}{l}\text { Try to make } \\
\text { arrangement with the } \\
\text { patron to research a } \\
\text { question }\end{array}$ & $\begin{array}{l}\text { Referral was } \\
\text { made/suggests } \\
\text { library visit }\end{array}$ & $\begin{array}{l}\text { I suggest you visit } \\
\text { the library for more } \\
\text { help with this type } \\
\text { of question; our } \\
\text { reference desk is } \\
\text { located at.... }\end{array}$ \\
\hline 5.7 Refers the patrons to other & Refer the patron to & Referral was made/ & You may want to \\
\hline
\end{tabular}




\begin{tabular}{|l|l|l|l|}
\hline $\begin{array}{l}\text { Sources or institutions when the } \\
\text { query cannot be answered to the } \\
\text { satisfaction of the patron. }\end{array}$ & other sources & $\begin{array}{l}\text { other sources outside } \\
\text { institution }\end{array}$ & $\begin{array}{l}\text { contact the national } \\
\text { archives }\end{array}$ \\
\hline $\begin{array}{l}\text { 5.8 Facilitates the process of } \\
\text { referring patrons to another } \\
\text { library or information agency } \\
\text { through activities such as calling } \\
\text { ahead, providing direction and } \\
\text { instructions, and providing the } \\
\text { library and the patrons with as } \\
\text { much information as possible } \\
\text { about the amount of information } \\
\text { required, and sources already } \\
\text { consulted. }\end{array}$ & $\begin{array}{l}\text { Provide directions and } \\
\text { reftructions when } \\
\text { referral was made. }\end{array}$ & $\begin{array}{l}\text { Referral was made/ } \\
\text { provide instructions } \\
\text { with referral }\end{array}$ & $\begin{array}{l}\text { When you go to } \\
\text { your library, ask } \\
\text { about "interlibrary } \\
\text { loan" and give the } \\
\text { librarian the title, } \\
\text { author, and } \\
\text { publication } \\
\text { information }\end{array}$ \\
\hline $\begin{array}{l}\text { 5.10 Suggests that the patrons } \\
\text { visit or call the library when } \\
\text { appropriate. }\end{array}$ & $\begin{array}{l}\text { Suggest that the patron } \\
\text { visit the library }\end{array}$ & $\begin{array}{l}\text { Referral was } \\
\text { made/suggests } \\
\text { library visit }\end{array}$ & $\begin{array}{l}\text { I suggest you visit } \\
\text { the library for more } \\
\text { help with this type } \\
\text { of question; our } \\
\text { reference desk is } \\
\text { located at.... }\end{array}$ \\
\hline
\end{tabular}


Table 3. Attributes table

\begin{tabular}{|c|c|c|}
\hline Attribute & Values & Method to determine value \\
\hline Question type & $\begin{array}{l}\text { Dissertation, Article, Book } \\
\text { chapter, Population, Topic, } \\
\text { Mascot }\end{array}$ & Determined before queries were sent \\
\hline $\begin{array}{l}\text { Adherence to turnaround } \\
\text { policies }\end{array}$ & Yes, No & $\begin{array}{l}\text { Institutions policies were compared to actual } \\
\text { number of days that it took the library to } \\
\text { respond }\end{array}$ \\
\hline Automatic response & Yes, No & $\begin{array}{l}\text { User received an automatic notification that } \\
\text { the query was received. }\end{array}$ \\
\hline User name & $\begin{array}{l}\text { Mary Anderson, Moshe } \\
\text { Cohen, Ahmed Ibrahim, } \\
\text { Latoya Johnson, Rosa } \\
\text { Manuz, Chang Su }\end{array}$ & Determined before queries were sent \\
\hline Semester & Fall, Spring & $\begin{array}{l}\text { The semester in which data collection took } \\
\text { place }\end{array}$ \\
\hline Response time & $1-200$ hours & $\begin{array}{l}\text { Number of hours for the library to respond } \\
\text { from the time the query was sent to the time } \\
\text { a response was received. }\end{array}$ \\
\hline Satisfaction & $1-3$ & $\begin{array}{l}\text { Mean score was calculated for each } \\
\text { transaction. }\end{array}$ \\
\hline Institution name & $1-54$ & $\begin{array}{l}\text { Each transaction was also coded according } \\
\text { to the institution that it was sent to. }\end{array}$ \\
\hline Response received & Yes, No & No response received by the user \\
\hline Length of reply & & $\begin{array}{l}\text { Number of words that the librarian wrote, } \\
\text { excluding automatic text (e.g., user } \\
\text { demographics, query) }\end{array}$ \\
\hline $\begin{array}{l}\text { Clicks to remote service } \\
\text { (RUSA only) }\end{array}$ & Yes, No & $\begin{array}{l}\text { Number of click ( } 2 \text { or less) from the main } \\
\text { library web page to the web form or email } \\
\text { address for asking remote reference } \\
\text { questions }\end{array}$ \\
\hline Uses web form (RUSA only) & Yes, No & $\begin{array}{l}\text { Whether the library uses a web form to } \\
\text { collect information for virtual reference. }\end{array}$ \\
\hline Weekend & Yes, No & $\begin{array}{l}\text { Whether or not the request was sent on the } \\
\text { weekend. }\end{array}$ \\
\hline
\end{tabular}


Table 4. Frequencies and percentage IFLA guidelines codes

Code

Answer/accurate answer

Answer/article sent

Answer/book chapter sent

Answer/dissertation/complete

Answer/mascot/complete

Answer/population question answered

Answer/subject/complete answer

Appropriate length and level

Authoritative sources

Automatic response

Broken link

Clarity of response

Closure/concluding remarks

Closure/contact information

Closure/department

Closure/initials of librarian

Closure/name of librarian

Evaluative remarks made

Follows time policy

Gives at least 1 resource

Greetings/hello

Greetings/name/with honorific

Includes heading, body, closure

Jargon

Misspelling

Neutral questioning

Objective behavior

Provides response time

Referral was made/library for further help

Referral was made/notification of inside referral

Refers directly to subject

Search strategies explained

Thank you for using
Frequency

85

9

1

44

15

40

0

209

135

87

3

293

152

97

203

30

205

2

201

18

166

25

202

10

3

9

293

231

13

15

138

27

96
Percent

72

15.7

3.5

75.8

25.4

68.9

0

64.5

41.6

26.7

0.9

90.4

46.9

29.9

62.6

9.2

63.2

0.6

62

30.5

50.6

7.7

62.3

3

0.9

2.7

90.4

71.2

4

4.6

42.5

8.3

29.6 
Table 5. Frequencies and percentage of RUSA guidelines codes

\begin{tabular}{|c|c|c|}
\hline Code & Frequency & Percent \\
\hline Answer/accurate answer & 85 & 72 \\
\hline Appropriate written language & 301 & 92.9 \\
\hline Ask what already tried & 2 & 0.6 \\
\hline Automatic response & 87 & 26.8 \\
\hline Closed questions & 12 & 3.7 \\
\hline Closure/concluding remarks & 152 & 46.9 \\
\hline Detailed info on sources & 113 & 34.8 \\
\hline Follow up & 91 & 28 \\
\hline Greetings/hello & 166 & 50.6 \\
\hline Greetings/name/first & 122 & 37.6 \\
\hline Greetings/name/full & 27 & 8.3 \\
\hline Greetings/name/with honorific & 25 & 7.7 \\
\hline Instructions provided - how to use & 23 & 7 \\
\hline Jargon (opposite) & 6 & 1.8 \\
\hline Objective & 298 & 91.9 \\
\hline Open questions & 3 & 0.9 \\
\hline Policies made public & 267 & 82.4 \\
\hline Policies made public/include question scope & 186 & 57.4 \\
\hline Policies made public/include turnaround time & 231 & 71.2 \\
\hline Policies made public/include type of answer provided & 1 & 0.3 \\
\hline $\begin{array}{l}\text { Policies made public/include type of answer } \\
\text { provided/instructions } \sim \text { scope }\end{array}$ & 20 & 6.1 \\
\hline $\begin{array}{l}\text { Policies made public/include type of answer } \\
\text { provided/only some resources }\end{array}$ & 6 & 1.8 \\
\hline $\begin{array}{l}\text { Policies made public/include type of answer } \\
\text { provided/via certain method }\end{array}$ & 15 & 4.6 \\
\hline Referral was made/more appropriate source & 8 & 2.4 \\
\hline Referral was made/other library services $\sim$ phone, in person & 16 & 4.9 \\
\hline Referral was made/provide instructions with referral & 8 & 2.4 \\
\hline Referral was made/suggests library visit & 20 & 6.1 \\
\hline Referral was made/to expert in library & 19 & 5.8 \\
\hline Referral was made/to other sources $\sim$ outside institution & 41 & 12.6 \\
\hline Rephrase the question & 31 & 9.5 \\
\hline Search strategies explained & 28 & 8.6 \\
\hline Suggests broader or narrower topic & 8 & 13.5 \\
\hline Thank you for using & 96 & 29.6 \\
\hline Two or less clicks to service & 270 & 83.3 \\
\hline Use webform & 306 & 94.4 \\
\hline
\end{tabular}


Table 6. Frequencies of IFLA guidelines codes by user name

\begin{tabular}{|c|c|c|c|c|c|c|}
\hline Code & $\begin{array}{l}\text { Mary } \\
\text { Anderson }\end{array}$ & $\begin{array}{l}\text { Moshe } \\
\text { Cohen }\end{array}$ & $\begin{array}{l}\text { Ahmed } \\
\text { Ibrahim }\end{array}$ & $\begin{array}{l}\text { Latoya } \\
\text { Johnson }\end{array}$ & $\begin{array}{l}\text { Rosa } \\
\text { Manuz }\end{array}$ & Chang Su \\
\hline Answer/accurate answer & 17 & 12 & 12 & 13 & 17 & 16 \\
\hline $\begin{array}{l}\text { Answer/article sent } \\
\text { (opposite) }\end{array}$ & 0 & 1 & 4 & 2 & 0 & 2 \\
\hline $\begin{array}{l}\text { Answer/book chapter sent } \\
\text { (opposite) }\end{array}$ & 0 & 0 & 0 & 1 & 0 & 0 \\
\hline Answer/dissertation/complete & 8 & 8 & 6 & 8 & 7 & 7 \\
\hline Answer/mascot/complete & 2 & 3 & 2 & 1 & 3 & 4 \\
\hline $\begin{array}{l}\text { Answer/population question } \\
\text { answered }\end{array}$ & 8 & 5 & 7 & 4 & 8 & 8 \\
\hline $\begin{array}{l}\text { Answer/subject/complete } \\
\text { answer }\end{array}$ & 0 & 0 & 0 & 0 & 0 & 0 \\
\hline Appropriate length and level & 31 & 30 & 33 & 39 & 38 & 38 \\
\hline Authoritative sources & 22 & 23 & 18 & 22 & 27 & 23 \\
\hline Automatic response & 15 & 14 & 14 & 16 & 14 & 14 \\
\hline Broken link & 0 & 0 & 2 & 0 & 1 & 0 \\
\hline Clarity of response & 48 & 48 & 48 & 51 & 52 & 46 \\
\hline Closure/concluding remarks & 19 & 32 & 20 & 25 & 30 & 26 \\
\hline Closure/contact information & 15 & 12 & 12 & 17 & 22 & 19 \\
\hline Closure/department & 36 & 31 & 32 & 37 & 36 & 31 \\
\hline Closure/initials of librarian & 6 & 5 & 5 & 5 & 3 & 6 \\
\hline Closure/name of librarian & 34 & 29 & 31 & 37 & 42 & 32 \\
\hline Evaluative remarks made & 0 & 0 & 0 & 1 & 1 & 0 \\
\hline Follows time policy & 29 & 35 & 33 & 34 & 36 & 34 \\
\hline Gives at least 1 resource & 4 & 1 & 2 & 3 & 4 & 4 \\
\hline Greetings/hello & 30 & 26 & 24 & 32 & 33 & 25 \\
\hline $\begin{array}{l}\text { Greetings/name/with } \\
\text { honorific }\end{array}$ & 8 & 4 & 2 & 5 & 6 & 0 \\
\hline $\begin{array}{l}\text { Includes heading, body, } \\
\text { closure }\end{array}$ & 33 & 35 & 32 & 33 & 39 & 30 \\
\hline Jargon (opposite) & 1 & 1 & 2 & 4 & 1 & 1 \\
\hline Misspelling (opposite) & 0 & 0 & 1 & 0 & 1 & 1 \\
\hline Neutral questioning & 1 & 2 & 1 & 0 & 4 & 1 \\
\hline Objective behavior (opposite) & 49 & 47 & 47 & 49 & 52 & 49 \\
\hline Provides response time & 36 & 36 & 39 & 40 & 41 & 39 \\
\hline $\begin{array}{l}\text { Referral was made/library for } \\
\text { further help }\end{array}$ & 2 & 3 & 3 & 3 & 0 & 2 \\
\hline Referral was made/link & 7 & 15 & 13 & 13 & 10 & 10 \\
\hline $\begin{array}{l}\text { Referral was } \\
\text { made/notification of inside } \\
\text { referral }\end{array}$ & 2 & 2 & 3 & 4 & 4 & 0 \\
\hline Refers directly to subject & 20 & 20 & 19 & 27 & 29 & 23 \\
\hline Thank you for using & 18 & 16 & 12 & 14 & 20 & 16 \\
\hline Total & 492 & 478 & 452 & 513 & 566 & 491 \\
\hline
\end{tabular}


Table 7. Frequencies of RUSA guidelines codes by user name

\begin{tabular}{|c|c|c|c|c|c|c|}
\hline Code & $\begin{array}{l}\text { Mary } \\
\text { Anderson }\end{array}$ & $\begin{array}{l}\text { Moshe } \\
\text { Cohen }\end{array}$ & $\begin{array}{l}\text { Ahmed } \\
\text { Ibrahim }\end{array}$ & $\begin{array}{l}\text { Latoya } \\
\text { Johnson }\end{array}$ & $\begin{array}{l}\text { Rosa } \\
\text { Manuz }\end{array}$ & Chang Su \\
\hline $\begin{array}{l}\text { Answer/accurate } \\
\text { answer }\end{array}$ & 17 & 12 & 11 & 13 & 17 & 16 \\
\hline $\begin{array}{l}\text { Appropriate written } \\
\text { language }\end{array}$ & 48 & 48 & 51 & 52 & 54 & 48 \\
\hline $\begin{array}{l}\text { Ask what already } \\
\text { tried }\end{array}$ & 0 & 0 & 0 & 0 & 1 & 1 \\
\hline Automatic response & 15 & 14 & 14 & 16 & 14 & 14 \\
\hline Closed questions & 1 & 3 & 2 & 2 & 4 & 0 \\
\hline $\begin{array}{l}\text { Closure/concluding } \\
\text { remarks }\end{array}$ & 19 & 32 & 20 & 25 & 30 & 26 \\
\hline $\begin{array}{l}\text { Detailed info on } \\
\text { sources }\end{array}$ & 17 & 26 & 15 & 19 & 17 & 19 \\
\hline Follow up & 13 & 15 & 12 & 16 & 21 & 14 \\
\hline Greetings/hello & 28 & 26 & 24 & 32 & 32 & 24 \\
\hline Greetings/name/first & 20 & 21 & 23 & 23 & 26 & 9 \\
\hline Greetings/name/full & 4 & 3 & 3 & 1 & 3 & 13 \\
\hline Greetings/name/last & 0 & 0 & 0 & 0 & 0 & 0 \\
\hline $\begin{array}{l}\text { Greetings/name/with } \\
\text { honorific }\end{array}$ & 8 & 4 & 2 & 5 & 6 & 0 \\
\hline $\begin{array}{l}\text { Instructions provided } \\
\text { - how to use }\end{array}$ & 2 & 4 & 7 & 1 & 6 & 3 \\
\hline Jargon (opposite) & 0 & 1 & 1 & 2 & 1 & 1 \\
\hline Objective & 48 & 49 & 47 & 52 & 53 & 49 \\
\hline Open questions & 1 & 0 & 0 & 1 & 1 & 0 \\
\hline Policies made public & 42 & 43 & 44 & 47 & 46 & 45 \\
\hline $\begin{array}{l}\text { Policies made public/ } \\
\text { include question } \\
\text { scope }\end{array}$ & 30 & 30 & 30 & 33 & 32 & 31 \\
\hline $\begin{array}{l}\text { Policies made public/ } \\
\text { include turnaround } \\
\text { time }\end{array}$ & 36 & 36 & 39 & 40 & 41 & 39 \\
\hline $\begin{array}{l}\text { Policies made public/ } \\
\text { include type of } \\
\text { answer provided }\end{array}$ & 0 & 0 & 1 & 0 & 0 & 0 \\
\hline $\begin{array}{l}\text { Policies made public/ } \\
\text { include type of } \\
\text { answer } \\
\text { provided/instructions } ~ \\
\text { scope }\end{array}$ & 3 & 3 & 3 & 3 & 4 & 4 \\
\hline $\begin{array}{l}\text { Policies made public/ } \\
\text { include type of } \\
\text { answer provided/only } \\
\text { some resources }\end{array}$ & 1 & 1 & 2 & 1 & 1 & 0 \\
\hline
\end{tabular}




\begin{tabular}{|c|c|c|c|c|c|c|}
\hline $\begin{array}{l}\text { Policies made public/ } \\
\text { include type of } \\
\text { answer provided/via } \\
\text { certain method }\end{array}$ & 2 & 3 & 2 & 3 & 2 & 3 \\
\hline $\begin{array}{l}\text { Referral was } \\
\text { made/link }\end{array}$ & 7 & 15 & 13 & 13 & 10 & 10 \\
\hline $\begin{array}{l}\text { Referral was } \\
\text { made/more } \\
\text { appropriate source }\end{array}$ & 1 & 2 & 0 & 1 & 3 & 1 \\
\hline $\begin{array}{l}\text { Referral was } \\
\text { made/other library } \\
\text { services } \sim \text { phone, in } \\
\text { person }\end{array}$ & 1 & 3 & 1 & 2 & 5 & 4 \\
\hline $\begin{array}{l}\text { Referral was made/ } \\
\text { provide instructions } \\
\text { with referral }\end{array}$ & 3 & 2 & 0 & 2 & 0 & 1 \\
\hline $\begin{array}{l}\text { Referral was made/ } \\
\text { suggests library visit }\end{array}$ & 3 & 4 & 3 & 5 & 2 & 3 \\
\hline $\begin{array}{l}\text { Referral was made/to } \\
\text { expert in library }\end{array}$ & 4 & 3 & 2 & 4 & 5 & 1 \\
\hline $\begin{array}{l}\text { Referral was made/to } \\
\text { other sources } \sim \text { outside } \\
\text { institution }\end{array}$ & 5 & 6 & 7 & 7 & 10 & 6 \\
\hline Rephrase the question & 7 & 7 & 3 & 4 & 5 & 5 \\
\hline $\begin{array}{l}\text { Search strategies } \\
\text { explained }\end{array}$ & 3 & 6 & 4 & 6 & 5 & 4 \\
\hline $\begin{array}{l}\text { Suggests broader or } \\
\text { narrower topic }\end{array}$ & 1 & 3 & 0 & 0 & 4 & 0 \\
\hline Thank you for using & 18 & 16 & 12 & 14 & 20 & 16 \\
\hline $\begin{array}{l}\text { Two or less clicks to } \\
\text { service }\end{array}$ & 45 & 45 & 45 & 46 & 45 & 44 \\
\hline Use webform & 51 & 51 & 51 & 52 & 51 & 50 \\
\hline Total & 497 & 520 & 479 & 526 & 565 & 492 \\
\hline
\end{tabular}


Table 8. Frequencies of IFLA and RUSA guidelines codes by institution and institutions' Ranking

\begin{tabular}{|c|c|c|c|c|}
\hline Institution & IFLA Frequencies & IFLA Rank & RUSA Frequencies & RUSA Rank \\
\hline 1 & 67 & 6 & 59 & 25 \\
\hline 2 & 45 & 39 & 59 & 27 \\
\hline 3 & 34 & 50 & 25 & 54 \\
\hline 4 & 55 & 22 & 70 & 5 \\
\hline 5 & 63 & 14 & 65 & 13 \\
\hline 6 & 65 & 10 & 64 & 17 \\
\hline 7 & 39 & 44 & 52 & 37 \\
\hline 8 & 70 & 4 & 68 & 10 \\
\hline 9 & 36 & 47 & 34 & 52 \\
\hline 10 & 50 & 32 & 61 & 22 \\
\hline 11 & 31 & 53 & 50 & 40 \\
\hline 12 & 59 & 18 & 71 & 4 \\
\hline 13 & 61 & 17 & 43 & 49 \\
\hline 14 & 52 & 30 & 57 & 32 \\
\hline 15 & 40 & 43 & 51 & 38 \\
\hline 16 & 43 & 40 & 46 & 46 \\
\hline 17 & 72 & 2 & 58 & 31 \\
\hline 18 & 68 & 5 & 58 & 29 \\
\hline 19 & 57 & 20 & 50 & 41 \\
\hline 20 & 59 & 19 & 63 & 18 \\
\hline 21 & 54 & 24 & 69 & 9 \\
\hline 22 & 46 & 38 & 57 & 33 \\
\hline 23 & 66 & 8 & 72 & 3 \\
\hline 24 & 65 & 9 & 70 & 6 \\
\hline 25 & 33 & 51 & 35 & 51 \\
\hline 26 & 47 & 37 & 54 & 36 \\
\hline 27 & 66 & 7 & 77 & 1 \\
\hline 28 & 52 & 28 & 67 & 11 \\
\hline 29 & 64 & 13 & 63 & 19 \\
\hline 30 & 64 & 11 & 69 & 8 \\
\hline 31 & 50 & 33 & 58 & 30 \\
\hline 32 & 53 & 26 & 60 & 24 \\
\hline 33 & 53 & 27 & 57 & 34 \\
\hline 34 & 56 & 21 & 63 & 20 \\
\hline 35 & 75 & 1 & 64 & 15 \\
\hline 36 & 36 & 48 & 31 & 53 \\
\hline 37 & 41 & 41 & 49 & 42 \\
\hline 38 & 31 & 52 & 60 & 23 \\
\hline 39 & 54 & 25 & 65 & 14 \\
\hline 40 & 62 & 15 & 64 & 16 \\
\hline 41 & 48 & 36 & 45 & 48 \\
\hline 42 & 51 & 31 & 46 & 47 \\
\hline 43 & 70 & 3 & 69 & 7 \\
\hline 44 & 64 & 12 & 66 & 12 \\
\hline 45 & 40 & 42 & 58 & 28 \\
\hline 46 & 52 & 29 & 59 & 26 \\
\hline
\end{tabular}




$\begin{array}{lllll}47 & 55 & 23 & 57 & 35 \\ 48 & 38 & 46 & 37 & 50 \\ 49 & 38 & 45 & 50 & 39 \\ 50 & 31 & 54 & 47 & 45 \\ 51 & 49 & 34 & 62 & 21 \\ 52 & 49 & 35 & 48 & 43 \\ 53 & 16 & 74 & 2 \\ 54 & 61 & 49 & 47 & 44\end{array}$


Table 9. Frequencies of IFLA guidelines codes by request type

\begin{tabular}{lllllll}
\hline Code & Dissertation & Mascot & Population & Topical & Article & Book \\
\hline Answer/accurate answer & 52 & 0 & 35 & 0 & 0 & 0 \\
Answer/article sent (opposite) & 0 & 0 & 0 & 0 & 9 & 0 \\
Answer/book chapter sent (opposite) & 0 & 0 & 0 & 0 & 0 & 1 \\
Answer/dissertation/complete & 44 & 0 & 0 & 0 & 0 & 0 \\
Answer/mascot/complete & 0 & 14 & 0 & 0 & 0 & 0 \\
Answer/population question answered & 0 & 0 & 41 & 0 & 0 & 0 \\
Answer/subject/complete answer & 0 & 0 & 0 & 10 & 0 & 0 \\
Appropriate length and level & 39 & 46 & 31 & 34 & 37 & 22 \\
Authoritative sources & 31 & 44 & 37 & 23 & 0 & 0 \\
Broken link (opposite) & 2 & 1 & 0 & 0 & 0 & 0 \\
Clarity of response & 51 & 57 & 51 & 52 & 55 & 27 \\
Closure/concluding remarks & 28 & 30 & 30 & 30 & 21 & 13 \\
Closure/contact information & 15 & 24 & 19 & 18 & 11 & 10 \\
Closure/department & 37 & 43 & 36 & 37 & 35 & 15 \\
Closure/initials of librarian & 8 & 6 & 6 & 3 & 6 & 1 \\
Closure/name of librarian & 36 & 47 & 33 & 35 & 35 & 19 \\
Consistent citation style & 0 & 1 & 2 & 0 & 0 & 0 \\
Evaluative remarks made & 0 & 1 & 0 & 1 & 0 & 0 \\
Follows time policy & 39 & 38 & 35 & 35 & 37 & 17 \\
Gives at least 1 resource & 0 & 1 & 0 & 17 & 0 & 0 \\
Greetings/hello & 30 & 35 & 26 & 30 & 33 & 16 \\
Greetings/name/with honorific & 6 & 6 & 6 & 5 & 4 & 2 \\
Includes heading, body, closure & 35 & 39 & 32 & 34 & 42 & 20 \\
Jargon (opposite) & 9 & 0 & 0 & 0 & 1 & 0 \\
Misspelling (opposite) & 0 & 1 & 2 & 0 & 0 & 0 \\
Neutral questioning & 0 & 1 & 0 & 4 & 4 & 0 \\
Objective behavior & 56 & 58 & 50 & 51 & 53 & 25 \\
Provides response time & 44 & 45 & 39 & 43 & 41 & 19 \\
Referral was made/inside referral & 1 & 6 & 6 & 2 & 0 & 0 \\
Referral was made/library for further help & 0 & 0 & 1 & 10 & 0 & 2 \\
Refers directly to subject & 30 & 31 & 29 & 30 & 11 & 7 \\
Search strategies explained & 1 & 1 & 6 & 9 & 10 & 0 \\
Thank you for using & 18 & 19 & 17 & 16 & 16 & 10 \\
Total & $\mathbf{5 6 7}$ & $\mathbf{5 6 2}$ & $\mathbf{5 4 7}$ & $\mathbf{4 9 9}$ & $\mathbf{4 2 3}$ & $\mathbf{2 1 6}$ \\
\hline & & & & & &
\end{tabular}


Table 10. Frequencies of RUSA codes by request type

\begin{tabular}{|c|c|c|c|c|c|c|}
\hline Codes & Dissertation & Mascot & Population & Topical & Article & Book \\
\hline$\overline{\text { Answer/accurate answer }}$ & 52 & 0 & 36 & 0 & 0 & 0 \\
\hline Appropriate written language & 57 & 59 & 50 & 54 & 55 & 26 \\
\hline Ask what already tried & 0 & 0 & 0 & 2 & 0 & 0 \\
\hline Automatic response & 14 & 15 & 15 & 17 & 15 & 11 \\
\hline Closed questions & 1 & 1 & 0 & 4 & 6 & 0 \\
\hline Closure/concluding remarks & 28 & 30 & 30 & 30 & 21 & 13 \\
\hline Detailed info on sources & 20 & 35 & 16 & 21 & 12 & 9 \\
\hline Follow up & 18 & 18 & 14 & 10 & 19 & 12 \\
\hline Greetings/hello & 28 & 34 & 26 & 30 & 32 & 16 \\
\hline Greetings/name/first & 21 & 21 & 19 & 25 & 25 & 11 \\
\hline Greetings/name/full & 2 & 7 & 5 & 2 & 7 & 4 \\
\hline Greetings/name/with honorific & 6 & 6 & 5 & 2 & 4 & 2 \\
\hline Instructions provided - how to use & 3 & 2 & 0 & 3 & 14 & 1 \\
\hline Jargon (opposite) & 4 & 0 & 0 & 0 & 2 & 0 \\
\hline Objective & 55 & 59 & 52 & 53 & 52 & 27 \\
\hline Open questions & 0 & 0 & 0 & 1 & 2 & 0 \\
\hline Policies made public & 51 & 52 & 45 & 49 & 48 & 22 \\
\hline Policies made public/include question scope & 35 & 37 & 31 & 34 & 32 & 17 \\
\hline Policies made public/include turnaround time & 44 & 45 & 39 & 43 & 41 & 19 \\
\hline $\begin{array}{l}\text { Policies made public/include type of answer } \\
\text { provided }\end{array}$ & 0 & 1 & 0 & 0 & 0 & 0 \\
\hline $\begin{array}{l}\text { Policies made public/include type of answer } \\
\text { provided/instructions } \sim \text { scope }\end{array}$ & 3 & 4 & 4 & 4 & 4 & 1 \\
\hline $\begin{array}{l}\text { Policies made public/include type of answer } \\
\text { provided/only some resources }\end{array}$ & 2 & 1 & 1 & 1 & 1 & 0 \\
\hline $\begin{array}{l}\text { Policies made public/include type of answer } \\
\text { provided/via certain method }\end{array}$ & 2 & 3 & 2 & 4 & 3 & 1 \\
\hline Referral was made/more appropriate source & 0 & 0 & 1 & 3 & 3 & 1 \\
\hline $\begin{array}{l}\text { Referral was made/other library services } \\
\sim \text { phone, in person }\end{array}$ & 2 & 0 & 0 & 6 & 5 & 3 \\
\hline $\begin{array}{l}\text { Referral was made/provide instructions with } \\
\text { referral }\end{array}$ & 5 & 0 & 2 & 1 & 0 & 0 \\
\hline Referral was made/suggests library visit & 0 & 1 & 0 & 7 & 2 & 10 \\
\hline Referral was made/to expert in library & 2 & 8 & 6 & 3 & 0 & 0 \\
\hline $\begin{array}{l}\text { Referral was made/to other sources } \sim \text { outside } \\
\text { institution }\end{array}$ & 4 & 2 & 5 & 8 & 13 & 9 \\
\hline Rephrase the question & 16 & 6 & 0 & 5 & 3 & 1 \\
\hline Search strategies explained & 2 & 1 & 6 & 9 & 10 & 0 \\
\hline Suggests broader or narrower topic & 0 & 0 & 0 & 8 & 0 & 0 \\
\hline Thank you for using & 18 & 19 & 17 & 16 & 16 & 10 \\
\hline Two or less clicks to service & 47 & 50 & 49 & 48 & 50 & 26 \\
\hline Use webform & 55 & 55 & 55 & 55 & 56 & 30 \\
\hline Total & 587 & 572 & 531 & 558 & 549 & 282 \\
\hline
\end{tabular}


Table 11. Adherence to time policies on weekdays and over the weekend

\begin{tabular}{lccc}
\hline Adherence to time policy & Weekend & Weekdays & Total \\
\hline Yes & 30 & 171 & 201 \\
No & 7 & 21 & 28 \\
Not Applicable & 9 & 86 & 95 \\
\hline Total & $\mathbf{4 6}$ & $\mathbf{2 7 8}$ & $\mathbf{3 2 4}$ \\
\hline
\end{tabular}


Table 12. Satisfaction, accuracy, and total frequency of adherence to IFLA and RUSA guidelines by institution

\begin{tabular}{|c|c|c|c|c|c|c|c|}
\hline $\begin{array}{c}\text { Institutio } \\
\mathbf{n}\end{array}$ & $\begin{array}{c}\text { Satisfactio } \\
\mathbf{n}\end{array}$ & $\begin{array}{c}\text { Answers } \\
\text { Receive } \\
\text { d }\end{array}$ & $\begin{array}{c}\text { Average } \\
\text { Satisfactio } \\
\text { n } \\
\text { (Rank) }\end{array}$ & $\begin{array}{c}\text { Accurat } \\
\text { e } \\
\text { Answer }\end{array}$ & $\begin{array}{c}\text { Complet } \\
\text { e } \\
\text { Answer }\end{array}$ & $\begin{array}{c}\text { Total } \\
\text { Frequencie } \\
\text { s } \\
\text { of IFLA } \\
\text { Codes } \\
\text { (Rank) }\end{array}$ & $\begin{array}{c}\text { Total } \\
\text { Frequencie } \\
\text { s } \\
\text { of RUSA } \\
\text { codes } \\
\text { (Rank) }\end{array}$ \\
\hline 1 & 11.33 & 5 & $2.26(24)$ & 2 & 2 & $67(6)$ & $59(25)$ \\
\hline 2 & 11 & 6 & $1.83(52)$ & 2 & 2 & 45 (39) & $59(27)$ \\
\hline 3 & 13.66 & 6 & $2.27(20)$ & 2 & 0 & $34(50)$ & $25(54)$ \\
\hline 4 & 15.5 & 6 & $2.58(6)$ & 1 & 3 & $55(22)$ & $70(5)$ \\
\hline 5 & 16.33 & 6 & $2.71(5)$ & 1 & 1 & $63(14)$ & $65(13)$ \\
\hline 6 & 11.33 & 5 & $2.26(25)$ & 3 & 4 & $65(10)$ & 64 (17) \\
\hline 7 & 14.66 & 6 & $2.44(12)$ & 1 & 1 & $39(44)$ & $52(37)$ \\
\hline 8 & 8 & 4 & $2(44)$ & 2 & 4 & $70(4)$ & $68(10)$ \\
\hline 9 & 16.66 & 6 & $2.77(3)$ & 0 & 1 & $36(47)$ & $34(52)$ \\
\hline 10 & 13 & 6 & $2.16(29)$ & 1 & 2 & $50(32)$ & $61(22)$ \\
\hline 11 & 12.33 & 6 & $2.05(40)$ & 2 & 3 & $31(53)$ & $50(40)$ \\
\hline 12 & 11.33 & 6 & $1.88(48)$ & 1 & 2 & 59 (18) & $71(4)$ \\
\hline 13 & 14.66 & 6 & $2.44(13)$ & 3 & 4 & $61(17)$ & $43(49)$ \\
\hline 14 & 13 & 6 & $2.16(30)$ & 1 & 1 & $52(30)$ & $57(32)$ \\
\hline 15 & 13.66 & 6 & $2.27(21)$ & 0 & 0 & $40(43)$ & $51(38)$ \\
\hline 16 & 10.66 & 5 & $2.13(35)$ & 2 & 2 & $43(40)$ & $46(46)$ \\
\hline 17 & 10 & 5 & $2(45)$ & 1 & 2 & $72(2)$ & $58(31)$ \\
\hline 18 & 13 & 6 & $2.16(31)$ & 3 & 3 & $68(5)$ & $58(29)$ \\
\hline 19 & 11.33 & 6 & $1.88(49)$ & 2 & 1 & $57(20)$ & $50(41)$ \\
\hline 20 & 11.33 & 5 & $2.26(26)$ & 3 & 3 & 59 (19) & $63(18)$ \\
\hline 21 & 13 & 6 & $2.16(32)$ & 1 & 1 & $54(24)$ & $69(9)$ \\
\hline 22 & 12.53 & 6 & $2.08(38)$ & 2 & 2 & $46(38)$ & $57(33)$ \\
\hline 23 & 12.5 & 5 & $2.5(8)$ & 1 & 2 & $66(8)$ & $72(3)$ \\
\hline 24 & 11.33 & 6 & $1.88(50)$ & 1 & 1 & $65(9)$ & $70(6)$ \\
\hline 25 & 12.33 & 6 & $2.05(41)$ & 1 & 1 & $33(51)$ & $35(51)$ \\
\hline 26 & 14.88 & 6 & $2.48(11)$ & 2 & 2 & $47(37)$ & $54(36)$ \\
\hline 27 & 12.83 & 6 & $2.13(36)$ & 2 & 2 & $66(7)$ & $77(1)$ \\
\hline 28 & 13.66 & 6 & $2.27(22)$ & 1 & 1 & $52(28)$ & $67(11)$ \\
\hline 29 & 13.33 & 6 & $2.22(28)$ & 2 & 2 & $64(13)$ & 63 (19) \\
\hline 30 & 11.83 & 5 & $2.36(17)$ & 1 & 2 & 64 (11) & $69(8)$ \\
\hline 31 & 13 & 6 & $2.16(33)$ & 2 & 1 & $50(33)$ & $58(30)$ \\
\hline 32 & 9.33 & 5 & $1.86(51)$ & 1 & 1 & $53(26)$ & $60(24)$ \\
\hline 33 & 12.33 & 6 & $2.05(42)$ & 2 & 2 & $53(27)$ & $57(34)$ \\
\hline 34 & 12.33 & 6 & $2.05(43)$ & 2 & 2 & $56(21)$ & $63(20)$ \\
\hline 35 & 15.16 & 6 & $2.52(7)$ & 2 & 1 & 75 (1) & $64(15)$ \\
\hline 36 & 16.83 & 6 & $2.8(1)$ & 1 & 2 & $36(48)$ & $31(53)$ \\
\hline 37 & 10 & 4 & $2.5(9)$ & 2 & 2 & $41(41)$ & $49(42)$ \\
\hline 38 & 10.66 & 5 & $2.13(37)$ & 2 & 1 & $31(52)$ & $60(23)$ \\
\hline 39 & 11.86 & 6 & $1.97(46)$ & 2 & 1 & $54(25)$ & $65(14)$ \\
\hline 40 & 11.66 & 5 & $2.33(18)$ & 0 & 0 & $62(15)$ & $64(16)$ \\
\hline 41 & 12.5 & 6 & $2.08(39)$ & 2 & 1 & $48(36)$ & $45(48)$ \\
\hline
\end{tabular}




$\begin{array}{llllllll}42 & 9 & 5 & 1.8(54) & 2 & 2 & 51(31) & 46(47) \\ 43 & 14.33 & 6 & 2.38(16) & 2 & 2 & 70(3) & 69(7) \\ 44 & 16.66 & 6 & 2.77(4) & 2 & 2 & 64(12) & 66(12) \\ 45 & 11.33 & 5 & 2.26(27) & 1 & 0 & 40(42) & 58(28) \\ 46 & 9.66 & 5 & 1.93(47) & 2 & 2 & 52(29) & 59(26) \\ 47 & 9.16 & 5 & 1.83(53) & 1 & 1 & 55(23) & 57(35) \\ 48 & 14.66 & 6 & 2.44(14) & 1 & 1 & 38(46) & 37(50) \\ 49 & 12 & 5 & 2.4(15) & 2 & 1 & 38(45) & 50(39) \\ 50 & 15 & 6 & 2.5(10) & 2 & 1 & 31(54) & 47(45) \\ 51 & 11.66 & 5 & 2.33(19) & 1 & 1 & 49(34) & 62(21) \\ 52 & 13 & 6 & 2.16(34) & 2 & 2 & 49(35) & 48(43) \\ 53 & 13.66 & 6 & 2.27(23) & 2 & 2 & 61(16) & 74(2) \\ 54 & 14 & 5 & 2.8(2) & 1 & 1 & 34(47) & 47(44)\end{array}$


Table 13. Correlations matrix

\begin{tabular}{llccccc}
\hline & & $\begin{array}{c}\text { Average } \\
\text { Satisfaction }\end{array}$ & IFLA & RUSA & Accuracy & Completeness \\
\hline Mean & & 2.24 & 52.11 & 56.90 & 1.59 & 1.64 \\
SD & .26 & 12.14 & 11.40 & .71 & .93 \\
$\mathbf{N}$ & & 54 & 54 & 54 & 54 & 54 \\
\hline Average & Pearson Correlation & & -.141 & -.185 & -.181 & -.045 \\
Satisfaction & Sig. (2-tailed) & & .310 & .180 & .189 & .746 \\
\hline IFLA & Pearson Correlation & & & $.697\left(^{* *}\right)$ & .205 & $.392\left(^{* *}\right)$ \\
& Sig. (2-tailed) & & & .000 & .136 & .003 \\
\hline RUSA & Pearson Correlation & & & & .032 & .222 \\
& Sig. (2-tailed) & & & & .816 & .107 \\
\hline
\end{tabular}

** Correlation is significant at the 0.01 level (2-tailed). 